Nyssen, J., Frankl, A., Mitiku Haile, Hurni, H., Descheemaeker, K., Crummey, D., Ritler, A., Portner, B., Nievergelt, B., Moeyersons, J., Munro, R.N., Deckers, J., Billi, P., Poesen, J., 2014. Environmental conditions and human drivers for changes to north Ethiopian mountain landscapes over 145 years. Science of the Total Environment, in press.

\title{
Environmental conditions and human drivers for changes to north Ethiopian mountain landscapes over 145 years
}

Jan Nyssen ${ }^{1}$, Amaury Frankl ${ }^{1}$, Mitiku Haile ${ }^{2}$, Hans Hurni ${ }^{3}$, Katrien Descheemaeker ${ }^{4}$, Donald Crummey $^{5, \dagger}$, Alfons Ritler $^{3}$, Brigitte Portner ${ }^{3}$, Bernhard Nievergelt ${ }^{6}$, Jan Moeyersons ${ }^{7}$, Neil Munro ${ }^{8}$, Jozef Deckers ${ }^{9}$, Paolo Billi ${ }^{10}$, Jean Poesen ${ }^{9}$

${ }^{1}$ Ghent University, Department of Geography, Gent, Belgium. ${ }^{2}$ Department of Land Resources Management and Environmental Protection, Mekelle University, Ethiopia. ${ }^{3}$ Department of Geography, University of Berne, Switzerland. ${ }^{4}$ Wageningen University, Wageningen, The Netherlands. ${ }^{5}$ Department of History, University of Illinois, United States of America. ${ }^{6}$ Institute of Zoology, Zürich University, Switzerland. ${ }^{7}$ Royal Museum for Central Africa, Tervuren, Belgium. ${ }^{8}$ Old Abbey Associates, Dirleton, Scotland, U.K. ${ }^{9}$ Department of Earth and Environmental Sciences, KU Leuven, Belgium. ${ }^{10}$ Earth Sciences Institute, University Ferrara, Italy. $\uparrow$ deceased author.

\footnotetext{
Abstract

As quantitative or spatially distributed studies of environmental change over truly long-term periods of more than 100 years are extremely rare, we re-photographed 361 landscapes that appear on historical photographs (1868-1994) within a 40,000 km² study area in northern Ethiopia. Visible evidence of environmental changes apparent from the paired photographs was analyzed using an expert rating system. The conditions of the woody vegetation, soil and water conservation structures and land management were worse in the earlier periods compared to their present conditions. The cover by indigenous trees is a notable exception: it peaked in the 1930s, declined afterwards and then achieved a second peak in the early $21^{\text {st }}$ century. Particularly in areas with greater population densities, there has been a significant increase in woody vegetation and soil and water conservation structures over the course of the study period. We conclude that except for an apparent upward movement of the upper tree limit, the direct human impacts on the environment are overriding the effects of climate change in the north Ethiopian highlands and that the northern Ethiopian highlands are currently greener than at any other time in the last 145 years.
} 
Keywords: reforestation, soil and water conservation, land management, woody vegetation, environmental rehabilitation, repeat photography

\section{Introduction}

The common perception of a far more luxuriant forest cover in the northern highlands of Ethiopia one hundred years ago (Allen-Rowlandson, 1989; Gore, 1992; Parry, 2003) has been challenged on the basis of historical and stratigraphic evidence (Nyssen et al., 2009; Pankhurst, 1995; Wøien, 1995). Whether the impact of climate change on land cover and geomorphological processes in such areas may override direct human impacts has been a topic of much debate. Great efforts have been undertaken in northern Ethiopia to control soil erosion at the regional scale, for instance, through the rehabilitation of steep slopes (Descheemaeker et al., 2006b; Descheemaeker et al., 2006c; Nyssen et al., 2007). Observational studies of land cover in Ethiopia date to the 1960s at the earliest, the age of the oldest available aerial photographs (Kebrom Tekle and Hedlund, 2000; Zeleke and Hurni, 2001). The recent rediscovery of large sets of historical terrestrial photographs (Nyssen et al., 2010) allows for this research to now extend back to 1868 , when the first landscape photographs were taken during a British military expedition to Ethiopia (Nyssen et al., 2009). To date, limited subsets of these historical photographs have been used to study certain time periods (Nyssen et al., 2009; Nyssen et al., 2008), but the increased availability of historical photographs and the relocation and rephotography of the sites they captured have made it possible to conduct trend analyses. In this paper, we present (1) a new methodology to analyze and present spatial trends in environmental changes that have occurred since the late $19^{\text {th }}$ century using the evidence provided by historical terrestrial photographs, (2) the application of this method to the northern Ethiopian highlands, and (3) an analysis of the drivers of the changes that have occurred.

*** Figure 1 approximately here $* * *$

\section{Study area}

The study area lies in the northern Ethiopian highlands between $11^{\circ}$ and $14^{\circ} 30^{\prime} \mathrm{N}$ (Fig. 1), extending over an area of ca. 40,000 $\mathrm{km}^{2}$. The major lithologies are Mesozoic sandstone and limestone and Tertiary volcanic rocks. Erosion in response to the Miocene and Plio-Pleistocene tectonic uplifts (on the 
order of $2500 \mathrm{~m}$ ) resulted in the formation of tabular, stepped landforms (between 2000 and $2800 \mathrm{~m}$ a.s.1.), reflecting the subhorizontal geological structure (Beyth, 1972; Kieffer et al., 2004; Merla, 1938). Mountain ranges rise locally to $3500 \mathrm{~m}$ a.s.l. The mean annual rainfall ranges from 560 to $1100 \mathrm{~mm} \mathrm{yr}^{-1}$ (1500 $\mathrm{mm} \mathrm{yr}^{-1}$ in the Simien Mts.), with a unimodal pattern (northern hemisphere summer rains), except in the southern part of the study area, where a second (shorter) rainy season in spring locally allows for the growth of two successive crops within one year (Frankl et al., 2013; Nyssen et al., 2005; Rosell and Holmer, 2007). Given the variability in precipitation patterns across the country (Nyssen et al., 2005), rainfall tendencies are also variable. The northwest has maintained a constant precipitation pattern, with a decline in the mid-1980s, whereas the northeast has experienced a decline in precipitation since 1996 (Verdin et al., 2005).

The dominant land use is small-scale, rain-fed subsistence agriculture, upon which the primary constraints are inadequate soil water availability and excessive soil erosion. In the $19^{\text {th }}$ and early $20^{\text {th }}$ centuries, a feudal land-tenure system prevailed, and for many people, the marginal slopes were the only accessible land resource (Fig. 2). More recently, the historical photographs generally show that the cultivated and forest/woodlot domains have been extended at the expense of rangeland (Fig. 3). *** Figure 2 approximately here $* * *$

*** Figure 3 approximately here $* * *$

Since the late 1970s, a land-tenure regime has been introduced, leading to an approximate equalization in the size of landholdings among households. Hendrie (1999) stated that "there is no single household or other kind of social group capable of concentrating land in large amounts", and this statement was still valid in 2013 in the study area. The total population size of Ethiopia (current boundaries) in 1868 was interpolated at 6.6 million from estimates dating back to 1820 and census results that began in the 1950s (Maddison, 2006; McEvedy and Jones, 1978). In contrast, the population in 2011 was approximately 82 million people. More precise historical data or estimates for the study area are not available. The low population numbers for the late $19^{\text {th }}$ and early $20^{\text {th }}$ centuries are corroborated by the small number of houses visible in the majority of the historical landscape photographs (Fig. 4). In addition to the famines and droughts that have occurred over the last 145 years, the Ethiopian environment has also undergone several impacts related to internal and international wars (Ståhl, 1990) (Fig. 3). Since the 1980s, soil and water conservation (SWC) techniques have been widely implemented, aimed at decreasing surface runoff and enhancing infiltration, sediment deposition and vegetation 
growth. In the semi-arid to subhumid study area, structures have been designed and constructed to conserve both soil and runoff (Ciampalini et al., 2012; Kumasi and Asenso-Okyere, 2011; Nyssen et al., 2007). Field studies conducted in the area by the authors beginning in 1972 allow for the interpretation of the quantitative findings of this long-term study.

*** Figure 4 approximately here $* * *$

\section{Materials and methods}

\subsection{Repeat photography}

In northern Ethiopia, 361 landscapes (Fig. 1, Table 1) pictured in historical photographs from as early as 1868 were recently re-photographed. As the name implies, repeat photography means retaking photographs from the same location and of the same subject several times; it requires the precise repositioning of the camera and composition of the subject (Hall, 2001), which in our case meant rephotographing a distant landscape. Landscape photographs of northern Ethiopia from as long ago as the “Abyssinia expedition” of 1868 were obtained (Nyssen et al., 2010). Different landscapes that were photographed in 1868, 1905-7, the 1930s, the 1940s, 1972-5 and 1994 were photographed again in the same season and at the same angle between 2006 and 2011 (Table 1). These photographs cover large parts of the northern Ethiopian highlands, from the Rift Valley shoulder between Adigrat and Kombolcha in the east, extending west to the Simien Mountains (Fig. 1), and they provide a fair representation of these landscapes since 1868. The location of the interpreted landscapes can be assumed to be random, insofar as the earlier photographers could not foresee the environmental changes that would occur in these areas. The majority of the archival photographs were taken by people in the military and researchers. Hence, to a large extent, they include places that are difficult to access. Photographs taken in landscapes with steep gradients are not, however, overrepresented in our dataset. The relocation of the historical photographs was based on the rough location indications written on some of the photographs, detailed scrutiny of maps of the travelers' routes, knowledge of landscape forms induced by various lithologies, and our geomorphological research experience in the study area. The camera positions were obtained through the identification of unique landscape features, such as mountain peaks and drainage ways, and their relative positions. Finally, the exact camera position and orientation were then obtained by aligning both near and distant objects in a triangulation system. 
Subsets of the same dataset of repeated photographs have been used in qualitative and semi-quantitative analyses of changes in land use and management between two moments in time (Crummey, 1998; Hurni, 2005; Munro et al., 2008; Nyssen et al., 2009), to map historical land uses in periods before the existence of aerial photography (Meire et al., 2013), to analyze climate-induced changes to the upper treeline (Nievergelt, 1998), to calibrate the categorization of historical land uses as derived from satellite imagery (de Mûelenaere et al., 2013), or to study gully development (Frankl et al., 2011).

*** Table 1 approximately here $* * *$

\subsection{Quantification using expert ratings}

Environmental changes apparent between paired photographs were analyzed using an expert rating system. Each of the 361 paired photographs was interpreted by 6 to 12 scientists with longstanding research experience in natural resources management in Ethiopia and elsewhere. The immediate foreground was masked for the analysis of the photographs, unless it had clear reference points. The repeat photography analysis involved the experts comparing the on-the-ground conditions from 20062011 with photographs depicting the historical conditions and assigning scores. Repeats of black and white photographs were also presented as black and white photographs. For each pair of photographs, the experts interpreted various indicators: total woody vegetation (including introduced eucalyptus trees that are well recognizable by their characteristic shape), woody vegetation excluding the eucalypts, physical SWC structures (stone bunds, check dams or soil bunds, see Figs. 2 and 5), and land management, incorporating visible evidence of physical and biological land conservation as well as the sustainable implementation of agriculture. Visible soil erosion features (rills, gullies, and recent sediment deposition) were considered but were difficult to interpret, except in a few cases. The 20062011 photographs were assigned a "zero" value (against which the older photographs were evaluated). For each pair of photographs, the evaluation of every indicator was then converted into a numerical score, ranging from +2 , indicating that the historical condition was "much better" than the current condition (2006-2011), to -2, indicating a "much worse" condition. Given that the scoring method used ordinal variables, the median score per indicator was calculated for each pair of photographs, provided that at least half of the experts thought that the indicator could be observed from the photographs.

*** Figure 5 approximately here $* * *$ 
We also considered the possible impacts of temperature changes in northern Ethiopia and their impacts in high mountain regions by analyzing the location of the upper limit of Erica arborea (the highest elevation tree species in Ethiopia) in the upper areas of the Inatye $\left(13^{\circ} 16^{\prime} \mathrm{N}, 38^{\circ} 10^{\prime} \mathrm{E}, 4070 \mathrm{~m}\right.$ a.s.1.) and the Silki massifs $\left(13^{\circ} 20^{\prime} \mathrm{N}, 38^{\circ} 16^{\prime} \mathrm{E}, 4420 \mathrm{~m}\right.$ a.s.1.) of the Simien Mountains after 1905. Seven repeat photographs with different and well-distributed slope aspects, located inside and outside of the national park, were analyzed by obtaining a consensus among the experts on the location of the uppermost Erica individuals in the repeat photographs. The elevations were then obtained by determining the observed heights on a topographic map.

\subsection{Spatio-temporal analysis of explanatory factors.}

Assuming equivalent intervals (Thurstone, 1928), the ordinal scale used in the photographic interpretations was converted to a quantitative interval scale, allowing for the statistical analysis and interpretation of the indicators. For each epoch (a period of 20-40 years covering a sufficient number of photographs, centered on the median year of all of the photographs), we calculated the means of the indicators for all sets of paired photographs. The ratings were then plotted against the central dates of the epochs, and the timelines represented by these curves were analyzed. We also performed a spatiotemporal analysis of the explanatory factors for the changes observed. All reliable interpretations of the paired photographs were averaged by polygons, generally 15 ' latitude by 15 ' longitude, representing the landscapes of the study area (Table 1). The polygon boundaries were adapted to fit the boundaries of the large area of urbanization surrounding Mekelle and to single out the Afro-alpine areas (above $3500 \mathrm{~m}$ a.s.1.). The area of a polygon varies with latitude, but each polygon was approximately $750 \mathrm{~km}^{2}$. All the photographs within a polygon were considered to be concentrated at its center.

*** Table 2 approximately here $* * *$

The calculated values of the indicators for each polygon allowed for an analysis of the spatial variability in environmental status over time. There were 14 raster points (regional averages of photo interpretations) for 1868-1925 (centered on 1900), 15 for 1926-1940 (1935), 4 for 1941-1965 (1950), 19 for 1966-1985 (1975), and 11 for 1986-2000 (1995). The mean ratings of woody vegetation (v) and soil and water conservation structures (s) were calculated for each raster point and compared with the evaluations from the 2006-2011 period. For instance, s1975 stands for the rating of SWC from 1966- 
1985, which is centered on 1975, and compared with the SWC condition from 2006-2011. Explanatory variables chosen based on our research experience in the study area were obtained for each polygon (Table 2):

- $\quad$ Monthly $\left(\mathrm{P}_{\mathrm{m}}\right.$, in $\left.\mathrm{mm}\right)$ and annual rainfall averages $\left(\mathrm{P}_{\mathrm{y}}\right.$, in $\left.\mathrm{mm}\right)$ were interpolated using NewLocClim (FAO, 2013) for the location at the center of each polygon. The interpolation (using a Gaussian distance function) was performed exclusively along a horizontal gradient, as only weak correlations exist between elevation and rainfall in the study area (Nyssen et al., 2005). For the Simien Mountains, the meteorological stations used by NewLocClim were too distant with elevations well below those of the mountains. Therefore, the data obtained during a measurement campaign conducted at Geech camp (3600 m a.s.l.) between 1968 and 1976 were used (Hurni, 1982), which recorded much higher values than the NewLocClim extrapolations.

- Fournier's (1962) degradation coefficient $\left(\mathrm{C}_{\mathrm{f}}\right.$, in $\left.\mathrm{mm}\right)$ was calculated using the equation:

$$
\mathrm{C}_{\mathrm{f}}=\mathrm{p}^{2} / \mathrm{P}_{\mathrm{y}}
$$

where $\mathrm{p}=$ the mean monthly precipitation $(\mathrm{mm})$ during the wettest month and

$$
\mathrm{P}_{\mathrm{y}}=\text { the mean annual precipitation }(\mathrm{mm}) \text {. }
$$

This coefficient expresses the fact that soil erosion in a specific area, especially under natural conditions, is dependent on the annual and seasonal rainfall. High values of $\mathrm{C}_{\mathrm{f}}$ were found in regions with strong seasonality, such as the Simien Mountains (despite its overall high yearly rainfall), and low values characterized areas with two rainy seasons, particularly the southern part of the study area. This relatively simple coefficient was used because it did not produce worse correlations than the more complex, modified degradation coefficient $\left(\mathrm{C}_{\mathrm{m}}\right)$ that includes all the months of the year:

$$
\mathrm{C}_{\mathrm{m}}=\Sigma \mathrm{p}_{\mathrm{i}}^{2} / \mathrm{P}_{\mathrm{y}}
$$

where $\mathrm{p}_{\mathrm{i}}=$ the mean precipitation of month $\mathrm{i}$, with i representing the different months of the year.

- $\quad$ The mean annual air temperature $\left(\mathrm{T}_{\mathrm{y}}\right.$, in $\left.{ }^{\circ} \mathrm{C}\right)$ was interpolated along an elevation gradient from neighboring stations using NewLocClim data (FAO, 2013). For the Simien Mountains, this vertical extrapolation was also used because the elevation gradient of monthly temperatures among neighboring, lower-lying stations was strong. 
- The aridity index (A) for these regions, which are characterized by dominant summer rainfall (Peel et al., 2007), was calculated as:

$$
\mathrm{A}=0.05\left(\mathrm{P}_{\mathrm{y}}+28\right) / \mathrm{T}_{\mathrm{y}}
$$

where the climate is classified as arid if A $<1$ and is progressively more humid as values for A increase. According to this classification system, none of the study polygons were categorized as arid. Mekelle, Lahama, and Hawzen had the lowest values of A (1.6-1.7), and the Simien Mountains had the highest values (> 8).

- $\quad$ The population density for each polygon in $2005\left(\mathrm{~d}\right.$, inhabitants $\left.\mathrm{km}^{-2}\right)$ was obtained from the gridded world population dataset (CIESIN and CIAT, 2005), which calculates the density as a weighted average of the population densities of the districts included within the polygons. Although the population of the study area increased greatly during the study period, the vast majority of the inhabitants of the study area have not urbanized and the patterns of population density were assumed to have not changed substantially over time. Therefore, the population density from 2005 may also represent the relative population density from the early $20^{\text {th }}$ century.

- $\quad$ The distance (Dist, in $\mathrm{km}$ ) to the nearest major town (Mekelle, Gondar or Dessie) was calculated from the center of each polygon, and the maximum Dist was $120 \mathrm{~km}$.

- The longitude $\left({ }^{\circ} \mathrm{E}\right)$ and latitude $\left({ }^{\circ} \mathrm{N}\right)$ of the center of each polygon were deemed to represent climatic gradients.

- The mean elevation (z, in $\mathrm{m}$ a.s.l.) of each polygon was obtained from a Digital Terrain Model at a resolution of $90 \mathrm{~m}$ (SRTM, 2013).

- $\quad$ The mean slope gradient (SG, in degrees) in each polygon was calculated using the 'Spatial Analyst' module of $\operatorname{ArcGIS}^{\circledR}$ (SRTM, 2013).

- The recent forest cover was estimated as the fractional area of closed forest cover from the 1990s $\left(\mathrm{F}_{\mathrm{c}}\right.$, in \%) within each polygon. A closed forest is particularly evident around the Rift Valley escarpment (Bryant et al., 1997).

- $\quad$ The estimated original forest cover prior to large-scale disturbances by humans (circa 8000 years ago) $\left(\mathrm{F}_{\mathrm{o}}\right.$, in \%) was determined for each polygon (Bryant et al., 1997). The percent coverage is well 
below $100 \%$ for many polygons, given that there are strong limitations to forest growth in terms of the climate, elevation, soil conditions and topography within the study area.

A regression analysis was performed to explore relationships between these explanatory variables and the values of the indicators of environmental change. To avoid multicollinearity among the various climatic variables and their derived parameters that are generally closely interrelated (Table 3), we used only the degradation coefficient $\left(\mathrm{C}_{\mathrm{f}}\right)$, which was more strongly correlated to the observed changes than the other climatic indicators.

*** Table 3 approximately here $* * *$

One might consider that correlations with geographical coordinates are not best represented by longitude and latitude, as the study area has a NNE-SSW rainfall gradient (Jacob et al., 2013). Recalculating coordinates after establishing a rotation of the axes, however, did not enhance the correlations and thus were not used further. Similarly, combining $F_{o}$ and $F_{c}$ into a recalculated $\delta F$ to represent changes in forest cover did not improve correlations. The strengths of the relationships among variables were measured using the Pearson correlation coefficient (r). The significance of these coefficients was tested at different probability levels (p) using F-tests (Beguin, 1979). The correlation between the interpreted indicators for each period and the potential explanatory factors were used to create a correlation matrix, as were the changes observed across the main observation periods, i.e., 1868-1925, 1926-1940, 19661985, and 2006-2011. This analysis allowed for an initial understanding of the driving forces of the observed environmental changes. The time periods from 1941-1965 and 1986-2000 were not used in this analysis because of the small number of polygons with a sufficient number of interpreted photographs for these dates. Multiple regression analysis was used to determine the magnitude of environmental change, which was explained by including several explanatory variables. Stepwise models were created, leaving out the least significant explanatory variable at each step (Beguin, 1979). To avoid multicollinearity, correlation matrices among the independent variables were inspected (Table 3) to ensure that significantly correlated variables were not included together in the multiple regressions. All of the statistical analyses were performed using the SPSS20 software (IBM, Armonk, NY, United States of America). In this analysis, the repeat photographs pertaining to the city of Mekelle were excluded because the changes observed there were related to urbanization, for which the explanatory factors are very different from those pertaining to changes in rural areas. 
As the explanatory factors for the multiple regression equations are spatially distributed, these regression equations were used as models to spatially represent the observed changes. This allowed for spatial interpolations among the center points, where the data for a given indicator in each polygon were located (Loveland and Acevedo, 2006). Maps were created in ArcGIS (Esri, Redlands, CA, United States of America) by calculating the equation outcomes for $1 \mathrm{~km}^{2}$ grid cells and using the values obtained from the above-mentioned spatially distributed thematic data as input variables.

\section{Results}

4.1. Trends in woody vegetation cover, soil and water conservation and land management

Despite being widely scattered across the study area and representing the full range of regional variability and diverse land management decisions and attitudes at the micro-scale (household or village), a similar temporal pattern was discerned for most of the changes observed in the 361 photographs. The interpretation of visible evidence for changes in woody vegetation, SWC and land management indicated that these were in a worse condition in the earlier years and had improved over time to their current status (Fig. 6); the poorest conditions occurred in approximately 1868 and in approximately 1975. In addition to the current optimum in land conditions, there appears to have been a second optimum in the 1930s, which was well documented by the numerous photographers accompanying the Italian army in 1935 and 1936 (Fig. 7). These trends are very clear for woody vegetation, SWC structures and land management. As there are doubts regarding the sustainability of eucalypt-dominated ecosystems in Ethiopia (Nyssen et al., 2006), we also analyzed changes in vegetation cover discounting the eucalypts (Fig. 6b). In that case, the most complete vegetation cover was achieved in the 1930s, with a second best optimum in 2010 .

*** Figure 6 approximately here $* * *$

*** Figure 7 approximately here $* * *$

$* * *$ Table 4 approximately here $* * *$

*** Figure 8 approximately here $* * *$ 


\subsection{Spatio-temporal variability of environmental changes}

The correlation matrix among independent variables (Table 3) reveals a remarkable correlation between the current population density $(\mathrm{d})$ and the degradation coefficient $\left(\mathrm{C}_{\mathrm{f}}\right)(\mathrm{R}=-0.57 ; \mathrm{P}<0.01)($ Fig. 8).

The analysis of the spatial variability focused on two dependent variables (woody vegetation and SWC structures) as functions of a set of environmental variables (bio-physical and population). The strengths of the correlations of the explanatory variables with the changes in woody vegetation cover and SWC (Table 4) vary widely; however, the multiple regression analysis suggests that the degradation coefficient $\left(\mathrm{C}_{\mathrm{f}}\right)$, population density $(\mathrm{d})$, latitude $(\mathrm{N})$, and current and original forest cover $\left(\mathrm{F}_{\mathrm{c}}\right.$ and $\left.\mathrm{F}_{\mathrm{o}}\right)$ explained most of the observed changes in the woody vegetation. For instance, the relative vegetation cover around 1900 (v1900) is best correlated in a multiple regression model with the population density $(d)$, latitude $(\mathrm{N})$ and current forest cover $\left(\mathrm{F}_{\mathrm{c}}\right)$ :

$$
\mathrm{v} 1900=-0.014 \mathrm{~d}+0.361 \mathrm{~N}+0.034 \mathrm{~F}_{\mathrm{c}}-4.739\left(\mathrm{R}^{2}=0.59, \mathrm{P}=0.097, \mathrm{n}=13\right) \quad \text { (4) }(\text { Table 5) }
$$

The negative sign of the impact of population density (d) indicates lower ratings for relative woody vegetation around 1900 compared with the present in areas with high population density and hence the greatest improvement since then. The positive sign of $\mathrm{N}$ indicates that the magnitude of improvements has been greatest in the northern parts of the study area, and the positive sign of $F_{c}$ indicates that the improvements since 1900 in woody vegetation cover tend to be greater in places where forests already grow.

*** Table 5 approximately here $* * *$

*** Figure 9 approximately here $* * *$

Mapping of eq. 4 (Fig. 9) reveals that the wider Simien massif had a better vegetation cover in approximately 1900, but the rest of the study area was in a poorer condition at the onset of the 20th century compared to the present. Although it is difficult to perform a formal analysis involving the calculation of commission and omission errors with this dataset of paired photographs, a certain number of archival photographs that could not be repeated under the same angle confirm the mapped tendencies (Fig. 4). 
The relative amount of woody vegetation cover in 1935 (v1935) is poorly correlated with all the explanatory factors. The best regression result is eq. 5 (Table 5). The relative vegetation cover in approximately 1975 (v1975) is essentially correlated with the original forest cover $\left(\mathrm{F}_{\mathrm{o}}\right)$ and latitude $(\mathrm{N})$

(eq. 6, Table 5). The relative vegetation cover at the end of the $20^{\text {th }}$ century (v1995) is poorly correlated with all of the explanatory factors, except for the original forest cover $\left(\mathrm{F}_{\mathrm{o}}\right)$ (eq. 7, Table 5).

The intermediate changes are also interesting, as longer periods may integrate the effects of different drivers at different times. The changes in the woody vegetation cover between 1900 and 1935 (v19351900) are well correlated $\left(\mathrm{R}^{2}=0.82\right)$ with the population density $(\mathrm{d})$ and the recent forest cover $\left(F_{c}\right)$ (eq. 8, Table 5). The changes to the vegetation cover between 1935 and 1975 (v19751935) are poorly correlated with all of the explanatory factors. Only the degradation coefficient $\left(\mathrm{C}_{\mathrm{f}}\right)$ is slightly $\left(\mathrm{R}^{2}\right.$ $=0.22)$ and weakly $(\mathrm{P} \sim 0.15)$ correlated to v19751935 (eq. 9, Table 5).

The relative status of SWC structures in approximately $1900(\mathrm{~s} 1900)$ is correlated $\left(\mathrm{R}^{2}=0.56 ; \mathrm{P}=0.111\right)$ with the population density $(\mathrm{d})$ and both the original and the recent forest covers $\left(\mathrm{F}_{\mathrm{o}}\right.$ and $\left.\mathrm{F}_{\mathrm{c}}\right)$. The negative sign of the impact of $d$ indicates lower ratings for SWC in approximately 1900 (as compared to the present) in areas with high population density. The negative sign of $F_{o}$ indicates that these ratings were lower than their present status in areas where the forest potential is high, and the positive sign of $F_{c}$ indicates that the difference in SWC between 1900 and the present (a strong improvement) was positive in places that have good (current) forest cover. In the late $19^{\text {th }}$ and early $20^{\text {th }}$ century, the SWC consisted essentially of leaving woody vegetation strips between croplands (Figs. 2 and 7).

The relative density of SWC structures in 1935 (s1935) is correlated with the current population density (d) and longitude (E), while the SWC in approximately 1975 (s1975) is correlated with the original forest cover $\left(\mathrm{F}_{\mathrm{o}}\right)$. The near-modern relative status of the $\mathrm{SWC}(\mathrm{s} 1995)$ is well correlated $\left(\mathrm{R}^{2}=0.67 ; \mathrm{P}=\right.$ 0.026) with the degradation coefficient $\left(\mathrm{C}_{\mathrm{f}}\right)$, longitude $(\mathrm{E})$ and original forest cover $\left(\mathrm{F}_{\mathrm{o}}\right)$.

\section{Discussion}

For this environmental change study, we have endeavored to separate the roles of human activities, natural ecological processes and political decisions in environmental change (Bičík et al., 2001; Hietel et al., 2005). Through repeated photography, our analysis shows that the recent status (2006-2011) of the 
examined environmental indicators is better than it was in earlier decades, second only to the 1930s for woody vegetation when not including eucalyptus (Fig. 6). The widespread perception of "everdwindling soil and forest resources" in the northern Ethiopian highlands is challenged by this study. That perception corresponds to changes that several generations of highlanders observed between the 1930s and the 1980s, but it is not in accordance with the current conditions. A great proportion (though not all) of the vegetation recovery (Figs. 4, 5, 7 and 10) is due to Eucalyptus, as was also previously observed (Crummey, 1998; Woldeamlak Bewket, 2003). The growth of economically important eucalyptus trees (Jagger and Pender, 2003; Pohjonen and Pukkala, 1988) has several environmental trade-offs in terms of allelopathy and water consumption, particularly in the dry season (Fritzsche et al., 2006; Masresha Fetene and Beck, 2004; Selamyihun Kidanu et al., 2005; Tilashwork Chanie et al., 2013). In Ethiopia, guidelines indicate not to grow eucalyptus in valley bottoms but rather as mixed stands on hillslopes (Nyssen et al., 2006). However, especially in the central part of the country, numerous fertile croplands have been converted into eucalyptus plantations because of the booming market for poles, which reaches as far as Khartoum (Dereje Jenbere et al., 2012; Tilashwork Chanie et al., 2013; Zenebe Mekonnen et al., 2007). In many countries, farmers in areas with low levels of natural forests and in close proximity to urban wood product markets engage in increased tree and shrub management. Such increased tree planting is qualified as 'forest transition', resulting from higher prices for wood products due to the scarcity of wood (the 'forest scarcity path') or higher wages and off-farm employment opportunities that encourage farmers to plant less labor-intensive tree crops (the 'economic development path') (Bensel, 2008; Rudel et al., 2005). Our observations regarding the decline in vegetation cover and conservation intensity from the 1970s-1980s are in line with the observation of gully development beginning from the 1960s and stabilization since the 1990s (Frankl et al., 2011).

*** Figure 10 approximately here ***

Although the study area ("northern Ethiopian Highlands") is frequently considered to be quite homogeneous, there are clear contrasts in climatic conditions (Table 2). Current population densities are not random but are negatively correlated to the degradation coefficient $\mathrm{C}_{\mathrm{f}}$ (Fig. 8), which indicates less human settlement in areas prone to land degradation. Within these highlands, the elevation and mean slope gradient are not correlated to population density; instead, climatic conditions have determined where people have settled. 
An increase in vegetation cover after 1868-1925 has occurred across most of the study area, particularly the (north-)eastern portion (Fig. 4 and 9). The strongest recovery has occurred in the most degraded areas. In contrast, in the western portion of the study area, where human settlement is thought to be only 200-500 years old (Hurni, 1975), woody vegetation cover has decreased since the early $20^{\text {th }}$ century. In addition to the seemingly abundant availability of soil and vegetation, these areas are also less accessible than the eastern portion of the study area. Both factors may induce a decreased focus on the conservation of soil and vegetation among the population and the authorities. When considering the woody vegetation cover at different times, notably from 1868-1925 (1900) and 1926-1941 (1935), decreases in cover are linked to high population densities (eq. 8), confirming the "open access" attitude that prevailed at that time. The spatial variability of the changes in vegetation cover between 1935 and 1975 was essentially linked to the regional variability in climate (eq. 9). From 1975 to the present, the increase in vegetation has been greatest in areas that were originally covered with primary forest (high values of $\mathrm{F}_{\mathrm{o}}$ ) and where the reforestation activities undertaken since the 1970s-1980s have been the most successful (eq. 6).

*** Figure 11 approximately here $* * *$

The population of Ethiopia, within its current boundaries, increased from approximately 6.6 million to 82 million between 1868 and 2011 (Nyssen et al., 2009) (Fig. 11). The degradation observed from the 1930s until the 1980s is related to land clearing for food and fuel production (Descheemaeker et al., 2006b; Descheemaeker et al., 2006c; Nyssen et al., 2007; Wøien, 1995), unequal access to the land (Lanckriet et al., 2014) and ecological shocks related to occurrences of drought and war (Fig. 11, a and c). The vast majority of gullies in the study area developed during that period (Frankl et al., 2011) (Fig. $11, \mathrm{~b})$. The land rehabilitation that has occurred since then, despite the greatly increased population density, is understandable when one considers the large-scale implementation of land management activities (Fig. 11, d), the effect of which has overridden that of uncontrolled causes of change, such as those observed earlier in the study period. Environmental recovery programs were initiated by the government in the early 1980s, with collective terracing and reforestation activities later initiated in the then rebel-controlled areas (Munro et al., 2008). These activities developed through a learning process, including some dysfunctional earlier interventions (Herweg and Ludi, 1999) but continue to be implemented today over a very large region (Ciampalini et al., 2012; Kumasi and Asenso-Okyere, 2011; Nyssen et al., 2007). Physical structures, most notably stone bunds, have been built (Fig. 2, 5, 10 and 12). The steady increase of physical SWC structures over time has also occurred simultaneously with the 
increase in population (Fig. 11) and is not sensitive to climatic variability. Another key intervention has been the closure of highly degraded areas to livestock, cultivation and indiscriminate tree felling. In these now-protected areas, which comprise up to 15\% of the land area (Descheemaeker et al., 2006b; Descheemaeker et al., 2006c) (Fig. 12), the observed increases in biodiversity and vegetation cover and density as well as the improvements in soil fertility are correlated to the time that has elapsed since land closure (Aerts et al., 2004; Descheemaeker et al., 2006a). The establishment of protected areas (exclosures) has also enhanced infiltration and biomass production, which together strongly promote land rehabilitation.

$* * *$ Figure 12 approximately here $* * *$

In the study area, $81 \%$ of households remain dependent on firewood for their energy needs. The exclosure policy has been and is a cornerstone of the dynamics of landscape recovery, which has allowed for concurrent increases in human population and vegetation cover. Firewood is available as a result of greater biomass production and the use of bark, leaves and branches of the widespread eucalyptus trees. Current policies aimed at decreased transportation of firewood between districts are valuable, considering the potentially tremendous effects of exporting wood over great distances, as shown in nearby Somalia, where large areas have now become devoid of trees due to the exportation of charcoal to the Gulf States (Baxter, 2007). Improved protection and management of remnant vegetation, enhancement of access to alternative sources of urban energy and changes in cooking habits (Bereket Kebede et al., 2002) are the highest priorities to sustain the current positive trends. At this stage, development is too recent to establish whether the study area is undergoing its "forest transition," which would mean that the changes in tree cover are no longer inversely proportional to changes in population density (Mather, 1990). The shift from deforestation to reforestation is still patchy in its distribution, but several elements that induce the forest transition (Lambin and Meyfroidt, 2011) are present in the study area: increasing population, increasing food production, forest scarcity, zoning of forestry land (exclosures) and the expansion of forest (eucalypt) plantations.

The strong influence of population density in several multiple regression equations that explain the increase in woody vegetation cover from that present at the beginning of the $20^{\text {th }}$ century and the current growth of (planted) eucalypts demonstrate that these changes have been essentially induced by direct human activity, in both cases of removal and regrowth. To date, except in the afro-alpine areas, we have found no evidence that the long-term changes in vegetation density in the study area are the result of 
either the effects of global changes, such as increases in air temperature or increases in atmospheric $\mathrm{CO}_{2}$ concentrations or global alterations of biogeochemical cycles (Lewis et al., 2009). The local increase in the elevation of the afro-alpine tree line in the Simien Mountains (Fig. 13) and in the Abune Yosef massif (Jacob et al., 2014) tend to indicate, however, that such impacts of global change exist at elevations that are not suitable for agriculture or eucalypt planting and most likely only there.

*** Figure 13 approximately here $* * *$

The regional variability in the changes in SWC is difficult to explain when considering the long time period since 1868. However, when examined over shorter time periods, some tendencies become clear. Similarly to the changes in vegetation cover, the observed SWC density increased between 1900 and 1935 in areas with higher population densities (eq. 15). For the changes between 1935 and 1975, we obtained a highly significant model (eq. 16) that includes the population density, longitude and original forest cover. From 1975 to the present, the increase in SWC was greatest in areas that had poor original forest cover $\left(\mathrm{F}_{\mathrm{o}}\right)$ (eq. 13; Fig. 10).

\section{Conclusions}

We have long thought that the extremely degraded environment of the 1970s was the anti-climax of a very long trend of deforestation, increase in human population and extractive land management (Munro et al., 2008; Nyssen et al., 2009). This study demonstrates that the situation was already bad at the beginning of the $20^{\text {th }}$ century and that the 1930 s was an intermediate optimum in terms of land management. The concept of land and vegetation as an open resource that can be freely used, clearly illustrated in the 1868 photographs of Bolago (Nyssen et al., 2009) and even in those from the late 1930s at Debar Ridge (Fig. 7), was later abandoned, and land management has been greatly taken care of since the last quarter of the $20^{\text {th }}$ century.

Concerning the status of the land in the northern Ethiopian highlands, there has been a general tendency towards a recent increase in vegetation cover compared with any other period over the last 145 years, with a second optimum in the first half of the $20^{\text {th }}$ century. This improved vegetation cover is the result of 30 years of intense rehabilitation activities as well as initiatives by farmers. Physical SWC follows the same trend. In the areas that were and are least degraded, such as the relatively recently settled Simien 
Mountains, degradation is on-going, whereas the eastern portion of the study area, which was already very degraded in 1868, has benefited from improved land management. In line with Tiffen et al. (1994) and Morris (2010), our studies for northern Ethiopia confirm that when the environment is exhausted, human society has no option but to be inventive in its relationship with the environment. The long-term trends in woody vegetation cover in the northern Ethiopian highlands, where the cover is now at its greatest extent since 1868, are an issue of global concern as they show that: (1) land degradation is not a monotonous trend but is highly variable over time; (2) the spatial distribution of early changes (19001935 ) is essentially induced by uncontrolled factors, such as population density or local climatic conditions, whereas recent changes are induced by conservation efforts (environmental recovery programs); (3) severe land degradation is not irreversible; and (4) except for an apparent upward movement of the upper tree limit, the direct human impact on the environment is overriding the effects of climate change.

\section{Acknowledgements}

Local inhabitants, field assistants and Mekelle University staff at various levels assisted in relocating the archival photographs. In addition to those obtained by several co-authors, we also appreciate the provision of archival photographs by: team members of the Tigrai Rural Development Study (1974-6), R. Trummer, L. Workman, F. Dramis, A. Crismer, Archivio Luce, Kings Own Regiment Museum at Lancaster (U.K.) and its curator P. Donnelly, Alinari (Florence, Italy), Istituto Geografico Militare Italiano (Florence, Italy), the Humphrey Winterton Collection of East African Photographs (Illinois, U.S.), Istituto Agronomico per l'Oltremare (Florence, Italy), Royal Geographical Society (London, U.K.), Australian War Memorial, Publifoto - Olycom SpA (Milano, Italy), Museum of Archaeology and Anthropology (Cambridge University, UK) and the SA military museum (Gauteng, South Africa). In addition to the authors, some repeat photographs were taken and portions of their interpretations were also made by J. Naudts, R. Pankhurst, A. Beel, S. de Mûelenaere, C. De Wolf, E. Meire and A.T. Grove. D. Gobbett (CSIRO) performed an internal review of the draft manuscript. The research team involved over the years was funded by various sources, including VLIR (Belgium), FWO (Belgium), Ghent University (Belgium), ODI (UK), IUCN (Switzerland). We also acknowledge the constructive comments made by two anonymous reviewers on an earlier version of this manuscript. 


\section{References}

Aerts R, Wagendorp T, November E, Behailu M, Deckers J, Muys B. Ecosystem thermal buffer capacity as an indicator of the restoration status of protected areas in the northern Ethiopian highlands. Rest. Ecol. 2004; 12: 586-596.

Allen-Rowlandson T. A new approach to wildlife conservation in Ethiopia and its relevance to the control of desertification. In: Verwey WD, editor. Nature management and sustainable development. IOS Press, Amsterdam, 1989, pp. 307-315.

Baxter Z. Somalia's Coal Industry. ICE Case Studies, 201. http://www1.american.edu/ted/ice/somalia-coal.htm (accessed on 23.12.2013), 2007.

Beguin H. Méthodes d'analyse géographique quantitative. Paris: Librairies Techniques, 1979.

Bensel T. Fuelwood, deforestation, and land degradation: 10 years of evidence from Cebu province, the Philippines. Land Degradation \& Development 2008; 19: 587-605.

Bereket Kebede, Almaz Bekele, Elias Kedir. Can the urban poor afford modern energy? The case of Ethiopia. Energy Policy 2002; 30: 1029-1045.

Beyth M. Paleozoic-Mesozoic sedimentary basin of Makalle outlier. Am. Assoc. Pet. Geol. Bull. 1972; 56: $2426-$ 2439.

Bičík I, Jeleček L, Štepánek V. Land-use changes and their social driving forces in Czechia in the 19th and 20th centuries. Land Use Policy 2001; 18: 65-73.

Bryant D, Nielsen D, Tangley L. The Last Frontier Forests: Ecosystems and Economies on the Edge. http://pdf.wri.org/lastfrontierforests.pdf, accessed on 23.12.2013. Washington, DC: World Resources Institute, 1997.

Ciampalini R, Billi P, Ferrari G, Borselli L, Follain S. Soil erosion induced by land use changes as determined by plough marks and field evidence in the Aksum area (Ethiopia). Agriculture, Ecosystems \& Environment 2012; 146: 197-208.

CIESIN, CIAT. Gridded Population of the World Version 3 (GPWv3): Population Density Grids. Palisades, NY: Socioeconomic Data and Applications Center (SEDAC), Columbia University, 2005.

Conway D. The climate and hydrology of the Upper Blue Nile River. The Geographical Journal 2000; 166: 49-62.

Crummey D. Deforestation in Wollo: process or illusion? J. Ethiop. Stud. 1998; 32: 1-41.

de Mûelenaere S, Frankl A, Mitiku Haile, Poesen J, Deckers J, Munro RN, et al. Historical landscape photographs for calibration of Landsat land use/cover (1972) in the northern Ethiopian highlands. Land Degradation \& Development 2013: online early view.

Dejenie T, Asmelash T, De Meester L, Mulugeta A, Gebrekidan A, Risch S, et al. Limnological and ecological characteristics of tropical highland reservoirs in Tigray, Northern Ethiopia. Hydrobiologia 2008; 610: 193 209.

Dereje Jenbere, Mulugeta Lemenih, Kassa H. Expansion of eucalypt farm forestry and Its determinants in Arsi Negelle district, South Central Ethiopia. Small-scale Forestry 2012; 11: 389-405.

Descheemaeker K, Muys B, Nyssen J, Poesen J, Raes D, Mitiku Haile, et al. Litter production and organic matter accumulation in exclosures of the Tigray highlands, Ethiopia. Forest Ecology and Management 2006a; 233: 21-35.

Descheemaeker K, Nyssen J, Poesen J, Raes D, Haile M, Muys B, et al. Runoff on slopes with restoring vegetation: A case study from the Tigray highlands, Ethiopia. Journal of Hydrology 2006b; 331: 219-241.

Descheemaeker K, Nyssen J, Rossi J, Poesen J, Mitiku Haile, Moeyersons J, et al. Sediment deposition and pedogenesis in exclosures in the Tigray Highlands, Ethiopia. Geoderma 2006c; 132: 291-314.

FAO. NewLocClim climate database and interpolation software. Rome, Italy: FAO. http://www.fao.org/nr/climpag/pub/en3 051002 en.asp, accessed on 23 December 2013. Roma: Food and Agriculture Organization of the United Nations, 2013. 
Fournier F. Map of Erosion Danger in Africa South of the Sahara. Explanatory Note. EEC, Commission for Technical Cooperation in Africa, 1962.

Frankl A, Jacob M, Mitiku Haile, Poesen J, Deckers J, Nyssen J. The effect of rainfall on the spatio-temporal variability of cropping systems and duration of the crop cover in the Northern Ethiopian Highlands. Soil Use and Management 2013; 29: 374-383.

Frankl A, Nyssen J, De Dapper M, Mitiku Haile, Billi P, Munro RN, et al. Linking long-term gully and river channel dynamics to environmental change using repeat photography (North Ethiopia). Geomorphology 2011; 129: 238-251.

Fritzsche F, Asferachew Abate, Masresha Fetene, Beck E, Weise S, Guggenberger G. Soil-plant hydrology of indigenous and exotic trees in an Ethiopian montane forest. Tree Physiology 2006; 26: 1043-1054.

Girmay Kassa, Crummey D, Descheemaeker K, Nyssen J. Land degradation and resilience in Wollo from the 1930s onwards, as derived from aerial and terrestrial photographs. In: Nyssen J, Asfawossen Asrat, Dramis F, Mohammed Umer, editors. Excursion guide to the North Ethiopian Highlands. International Association of Geomorphologists, Regional Conference 2011, Addis Ababa, 2011, pp. 22-29.

Gore A. The earth in balance: ecology and the human spirit. Vol 416 Boston: Houghton Mifflin, 1992.

Hall F. Ground-based Photographic Monitoring. Gen. Tech. Rep. PNW-GTR-503. Portland, OR: U.S. Department of Agriculture, Forest Service, Pacific Northwest Research Station, 2001.

Hendrie B. Now the People are like a Lord - Local Effects of Revolutionary Reform in a Tigray Village, Northern Ethiopia. PhD dissertation. University College London, London, 1999.

Herweg K, Ludi E. The performance of selected soil and water conservation measures--case studies from Ethiopia and Eritrea. Catena 1999; 36: 99-114.

Hietel E, Waldhardt R, Otte A. Linking socio-economic factors, environment and land cover in the German Highlands, 1945-1999. Journal of Environmental Management 2005; 75: 133-143.

Hurni H. Bodenerosion in Semien-Aethiopien (mit Kartenbeilage 1:25 000). Geographica Helvetica 1975; 4: 157168.

Hurni H. Klima und Dynamik der Höhenstufung von der letzten Kaltzeit bis zur Gegenwart. Hochgebirge von Semien-Äthiopien. Vol G13, 1982.

Hurni H. Decentralised development in remote areas of the Simen Mountains, Ethiopia. Berne, Switzerland, 2005.

Jacob M, Frankl A, Beeckman H, Gebrekidan Mesfin, Hendrickx M, Etafa Guyassa, et al. Treeline dynamics and afro-alpine forest cover change in north Ethiopia since the early 20th century. Land Degrad. Develop. 2014: submitted.

Jacob M, Frankl A, Mitiku Haile, Zwertvaegher A, Nyssen J. Assessing spatio-temporal rainfall variability in a tropical mountain area (Ethiopia) using NOAAs Rainfall Estimates. International Journal of Remote Sensing 2013; 34: 8305-8321

Jagger $\mathrm{P}$, Pender J. The role of trees for sustainable management of less-favored lands: the case of eucalyptus in Ethiopia. Forest Policy And Economics 2003; 5: 83- 95

Kebrom Tekle, Hedlund L. Land cover changes between 1958 and 1986 in Kalu District, Southern Wello, Ethiopia. Mountain Res. Dev. 2000; 20: 42-51.

Kieffer B, Arndt N, Lapierre H, Bastien F, Bosch D, Pecher A, et al. Flood and shield basalts from Ethiopia: magmas from the African superswell. Journal of Petrology 2004; 45: 793-834.

Kumasi T, Asenso-Okyere K. Responding to Land Degradation in the Highlands of Tigray, Northern Ethiopia. Vol 01142: International Food Policy Research Institute, 2011.

Lambin EF, Meyfroidt P. Global land use change, economic globalization, and the looming land scarcity. Proceedings of the National Academy of Sciences 2011; 108: 3465-3472.

Lanckriet S, Derudder B, Naudts J, Bauer H, Deckers J, Mitiku Haile, et al. A political ecology perspective of land degradation in the north Ethiopian highlands. Land Degradation \& Development 2014: online early view. 
Lewis SL, Lopez-Gonzalez G, Sonke B, Affum-Baffoe K, Baker TR, Ojo LO, et al. Increasing carbon storage in intact African tropical forests. Nature 2009; 457: 1003-1006.

Loveland TR, Acevedo W. Land Cover Change in the Eastern United States. In: Acevedo W, Jellison PJ, editors. Status and Trends of Eastern United States Land Cover, http://landcovertrends.usgs.gov/east/regionalSummary.html, accessed on 23.12.2013. USGS, 2006.

Maddison A. The World Economy. Paris: OECD, Development Centre Studies, 2006.

Masresha Fetene, Beck EH. Water relations of indigenous versus exotic tree species, growing at the same site in a tropical montane forest in southern Ethiopia. Trees 2004; 18: 428-435.

Mather AS. Global Forest Resources. London: Belhaven, 1990.

McEvedy C, Jones R. Atlas of World Population History. Middlesex: Penguin 1978.

Meire E, Frankl A, De Wulf A, Mitiku Haile, Deckers J, Nyssen J. Land use and cover dynamics in Africa since the nineteenth century: warped terrestrial photographs of North Ethiopia. Regional Environmental Change 2013; 13: 717-737.

Merla G. I depositi intervulcanici. In: Merla G, Minucci E, editors. Missione geologica nel Tigrai. Reale Accademia d'Italia, Roma, 1938, pp. 332-336.

Morris I. Why the West Rules - For Now: The Patterns of History, and What they Reveal About the Future. New York: Farrar, Straus and Giroux, 2010.

Munro RN, Deckers J, Grove AT, Mitiku Haile, Poesen J, Nyssen J. Soil and erosion features of the Central Plateau region of Tigrai - Learning from photo monitoring with 30 years interval. Catena 2008; 75: 55-64.

Nievergelt B. Long-term changes in the landscape and ecosystems of the Simen Mountains National Park. Walia, special issue 1998: 8-23.

Nyssen J, Frankl A, Munro RN, Billi P, Mitiku Haile. Digital Photographic Archives for Environmental and Historical Studies: An Example from Ethiopia. Scottish Geographical Journal 2010; 126: 185 - 207.

Nyssen J, Mitiku Haile, Nauds J, Munro N, Poesen J, Moeyersons J, et al. Desertification? Northern Ethiopia rephotographed after 140 years. Science of the Total Environment 2009; 407: 2749-2755.

Nyssen J, Poesen J, Descheemaeker K, Nigussie Haregeweyn, Mitiku Haile, Moeyersons J, et al. Effects of regionwide soil and water conservation in semi-arid areas: the case of northern Ethiopia. Zeitschrift für Geomorphologie 2008; 52: 291 - 315.

Nyssen J, Poesen J, Desta Gebremichael, Vancampenhout K, D'Aes M, Gebremedhin Yihdego, et al. Interdisciplinary on-site evaluation of stone bunds to control soil erosion on cropland in Northern Ethiopia. Soil and Tillage Research 2007; 94: 151-163.

Nyssen J, Poesen J, Veyret-Picot M, Moeyersons J, Mitiku Haile, Deckers J, et al. Assessment of gully erosion rates through interviews and measurements: a case study from Northern Ethiopia. Earth Surf. Proc. Landf. 2006; 31: 167-185.

Nyssen J, Vandenreyken H, Poesen J, Moeyersons J, Deckers J, Mitiku Haile, et al. Rainfall erosivity and variability in the Northern Ethiopian Highlands. Journal of Hydrology 2005; 311: 172-187.

Pankhurst R. The history of deforestation and afforestation in Ethiopia prior to World War I. Northeast African Studies 1995; 2: 119-133.

Parry J. Tree choppers become tree planters. Appropriate Technology 2003; 30: 38-39.

Peel MC, Finlayson BL, McMahon TA. Updated world map of the Köppen-Geiger climate classification. Hydrology and Earth System Sciences 2007; 11: 1633-1644.

Pohjonen V, Pukkala T. Profitability of establishing Eucalyptus globulus plantations in the Central Highlands of Ethiopia. Silva Fennica 1988; 22: 307-321.

Rosell S, Holmer B. Rainfall change and its implications for Belg harvest in South Wollo, Ethiopia. Geogr. Ann. 2007; 89A: 287-299.

Rudel TK, Coomes OT, Moran E, Achard F, Angelsen A, Xu J, et al. Forest transitions: towards a global understanding of land use change. Global Environmental Change Part A 2005; 15: 23-31. 
Selamyihun Kidanu, Tekalign Mamo, Stroosnijder L. Biomass production of Eucalyptus boundary plantations and their effect on crop productivity on Ethiopian highland Vertisols. Agroforestry Systems 2005; 63: 281290.

SRTM. CGIAR Consortium for Spatial Information, SRTM 4410 (90 m resolution). http://srtm.csi.cgiar.org/. 23 May 2013, 2013.

Ståhl M. Environmental Degradation and Political Constraints in Ethiopia. Disasters 1990; 14: 140-150.

Thurstone L. Attitudes can be measured. American Journal of Sociology 1928; 33: 529-554.

Tiffen M, Mortimore M, Gichuki F. More people, less erosion: environmental recovery in Kenya. Chichester: Wiley, 1994.

Tilashwork Chanie, Collick AS, Enyew Adgo, Lehmann CJ, Steenhuis TS. Eco-hydrological impacts of Eucalyptus in the semi humid Ethiopian Highlands: the Lake Tana Plain. Journal of Hydrology and Hydromechanics. 61, 2013, pp. 21-29.

Verdin J, Funk C, Senay G, Choularton R. Climate science and famine early warning. Philosophical Transactions of the Royal Society B 2005; 360: 2155-2168.

Wøien H. Deforestation, information and citations: a comment on environmental degradation in Highland Ethiopia. Geojournal 1995; 37: 501-512.

Woldeamlak Bewket. Household level tree planting and its implications for environmental management in the northwestern highlands of Ethiopia: a case study in the Chemoga watershed, Blue Nile basin. Land Degradation \& Development 2003; 14: 377-388.

Zeleke G, Hurni H. Implications of land use and land cover dynamics for mountain resource degradation in the Northwestern Ethiopian highlands. Mountain Research and Development 2001; 21: 184-191.

Zenebe Mekonnen, Habtemariam Kassa, Mulugeta Lemenh, Campbell B. The role and management of eucalyptus in Lode Hetosa district, Central Ethiopia. Forests, Trees and Livelihoods 2007; 17: 309-323. 


\section{Figure captions}

Fig. 1 - Location of the study area. The topography is represented by contour lines at an equidistance of $500 \mathrm{~m}$. Dots indicate the locations of the historical photographs that were re-photographed and the polygon they were attributed to for analysis. Polygon codes and details of the archival photographs polygon are presented in Table 1.

Fig. 2 - View from the Zej Maryam church forest (2900 m a.s.1.) towards the Simien escarpment (in the TE polygon of Fig. 1) in 1905 (left: (C F. Rosen) and 2004 (right; (C) H. Hurni). The permanence in the land use system is shown not only by the forest but also by the presence of farmlands in relatively level areas and rangelands on the steepest slopes in both photographs. Stone bunds have been recently established on the nearest farmland, whereas on the next farmland, soil bunds have been maintained for more than a century. In recent decades, eucalypts have appeared on the farm boundaries, as in most of the study area. Although even steeper slopes were cultivated in this region in the intermediate period (Nievergelt, 1998), some cultivation of steep slopes in 2004 is noteworthy.

Fig. 3 - The barren slopes of Amba Alage (in the MA polygon in Fig. 1) have been partially reforested with eucalypts since 1941. Some Juniperus have also become established, but they have not grown to heights of more than a few meters. This image is part of a set of propaganda photographs dating back to the South African involvement in the British-led war against Italy in Ethiopia. The South African troops are facing the Italian army, which had fortified positions around Amba Alage (not visible in the photograph). The extent to which the degradation of the slopes is the result of intense warfare in that location $(1889$, 1895, 1941, 1943) remains unknown. 1941 photograph (C) SA military museum, Gauteng, South Africa; 2009 photograph (C) J. Nyssen. The matching black and white archival photographs were also interpreted as black and white photographs for the quantitative study.

Fig. 4 - This 1868 photograph near Adigrat (AD polygon in Fig. 1) could not be repeated because of the strong vegetation growth by 2007 and was not used in the formal analysis. Hence, it is an independent observation of a totally barren landscape that confirms the strong degradation of the vegetation cover in that area, which was mapped in approximately 1900 (Fig. 9). 1868 photograph @ King's Own Royal Regiment Museum; 2007 photograph (C) Jozef Naudts.

Fig. 5 - The archival photographs by A. Maugini (1937) in South Wollo (@ Istituto Agronomico per l'Oltremare, Firenze) were repeated in 1996 by D. Crummey and then again by K. Descheemaeker in 
2009. The village of Kundi (in the HY polygon in Fig. 1) has expanded throughout the study period, in accordance with known population growth. Stone bunds have been established in the farmlands. The expansion of eucalyptus grown on farm boundaries, private woodlots and steep slopes is typical and very pronounced in the southern, wetter portion of the study area. The bushes on the front slope had largely disappeared between 1937 and 1997 but had regrown by 2009. The repeat photo analysis for South Wollo has been confirmed by an independent study (Girmay Kassa et al., 2011) of aerial photographs taken since 1936.

Fig. 6 - Long-term trends of (a) woody vegetation, (b) woody vegetation without eucalypts, (c) SWC structure density, and (d) land management, as derived from analyzed historical terrestrial photographs and the mean values $( \pm S D)$ of the interpreted photographs for each epoch. The number of interpreted photographs per epoch ranges from 15 (1868) to 154 (epoch centered on 1975). The photographic interpretations compared the previous conditions pictured with those of 2010 (the reference situation), which were ranked with a value between -2 ("much worse") and +2 (“much better").

Fig. 7 - Important shifts in vegetation and SWC structures occurred around the Debar basalt escarpment (in the MA polygon in Fig. 1). The remnant Juniperus trees in the late 1930s are evidence of a vegetation optimum. In the period thereafter, nearly all of the woody vegetation in the undulating lands in the foreground was cleared and farmlands were established, including strip lynchets. On the scree slopes at the foot of the escarpment, the tree cover was approximately the same in both years, and the far mountains were reforested in the 1980s as mixed Juniperus-Eucalyptus forests. Although the entire area was open-access in the 1930s, the land use system has since been reorganized with clearly demarcated crop and forest lands. Archival photograph (C G. Merla; 2009 photograph @ J. Nyssen.

Fig. 8 - Current population densities for each polygon of the study area vs. the Fournier'sdegradation coefficient $\left(\mathrm{C}_{\mathrm{f}}\right)$ (Fournier, 1962) calculated for the centers of the respective polygons.

Fig. 9 - Relative status of the vegetation cover for the period from 1868-1925 compared with 2006-2011 based on the extrapolation (eq. 4) of the interpretation of repeated photographs (grouped in polygons). For those portions of the study area for which information is not available (absence of repeated archival photographs), no extrapolations were made, which explains the blank sectors on the map. For the purpose of illustration, the observed changes in vegetation cover are represented by the curves for five districts that had a good temporal coverage of historical photographs: Adigrat (AD), Agula'e (AG), 
Simien Bwahit (SB), Korem (KO) and Hayk (HY) (locations shown in Fig. 1). Interpretations compared the previous conditions pictured with those from 2006-2011 (the reference situation), which were ranked with a value between -2 ("much worse") and +2 ("much better").

Fig. 10 - View of Lake Ashenge (in the KO polygon in Fig. 1), which has the most complete incidental time series of repeat photographs in the $40,000 \mathrm{~km}^{2}$ wide study area. Permanence is observed in areas dedicated to agricultural land uses, which are essentially limited to the valley bottom, except that stone bunds have been built in recent decades. The vegetation cover on the hill was relatively dense in 1937 and decreased over time; in 1994, new houses and more vegetation appeared, but in 2008, the gully remained as a scar on the landscape. 1937 photograph by A. Maugini () Istituto Agronomico per l'Oltremare, Firenze; 1961 photograph @ A.T. (Dick) Grove; 1975 photograph @ R. Neil Munro; 1994 photograph () A. Crismer; 2008 photograph ( ) S. de Mûelenaere (repeat of the 1975 scene). The gully development represented in this scene is in accordance with land cover changes (Frankl et al., 2011).

Fig. 11 - Long-term trends in woody vegetation cover and physical SWC (determined as in Fig. 6) contrasted with the total population of Ethiopia (after Maddison, 2006; McEvedy and Jones, 1978) and the trend in annual rainfall in the Blue Nile basin (10-year moving average (Conway, 2000), extrapolated until 2011 using rainfall data from Bahir Dar). Conspicuous events, related to environmental changes in the study area, include: (a) drought, a war situation and weak authority; (b) region-wide appearance of gullies (Frankl et al., 2011); (c) drought, famine, civil war, and the start of land reform and land management efforts; and (d) widespread implementation of land management, enhanced by better rain conditions.

Fig. 12 - View towards Mt. Amba Aradam (2768 m a.s.l.) from the slopes of Mt. Hinda Haswa (KW polygon in Fig. 1). The characteristic expansion of vegetation between 1936 and 2010 includes the regrowth of the bushes in the foreground as a result of the establishment of an exclosure (in 1997, in this case), eucalypts planted near homesteads (center right of the repeat photograph) and irrigated agriculture, fed by the Hiza'eti Wedi Cheber earth dam established in 1997 (Dejenie et al., 2008). The vegetation on the contour accentuates the subhorizontal structural relief, which is further emphasized in the 2010 photograph by the establishment of stone bunds on the edges of hard rock layers. 1936 
photograph (C) Archivio Luce; 2010 photograph @ Jan Nyssen. The watermark hinders the artistic quality of the archival photograph but causes no significant problems for the interpretation of the landscape.

Fig. 13 - The elevation of the upper tree limit on the Inatye ridge (ridgetop at $4070 \mathrm{~m}$ a.s.l.) in the Simien Mts. increased between 1968 and 2012; the elevation of the uppermost individuals of Erica arborea on this SE-facing slope was estimated at $3780 \mathrm{~m}$ a.s.1. for 1966 and $3900 \mathrm{~m}$ a.s.1. for 2012. 1968 and 1996 photographs @ Bernhard Nievergelt; 2012 photograph @ Cleo De Wolf. 


\section{Figures}

Fig. 1

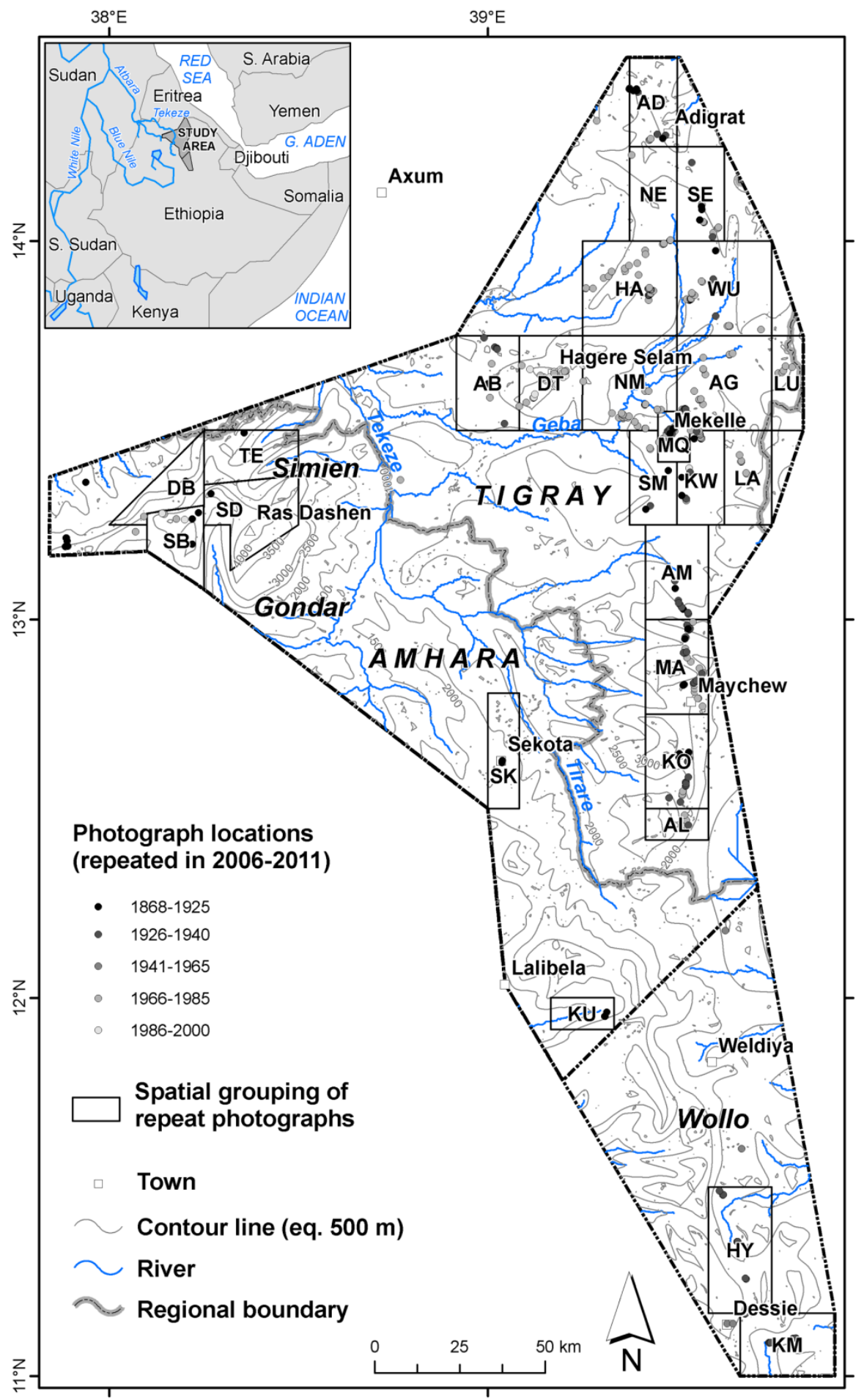


Fig. 2
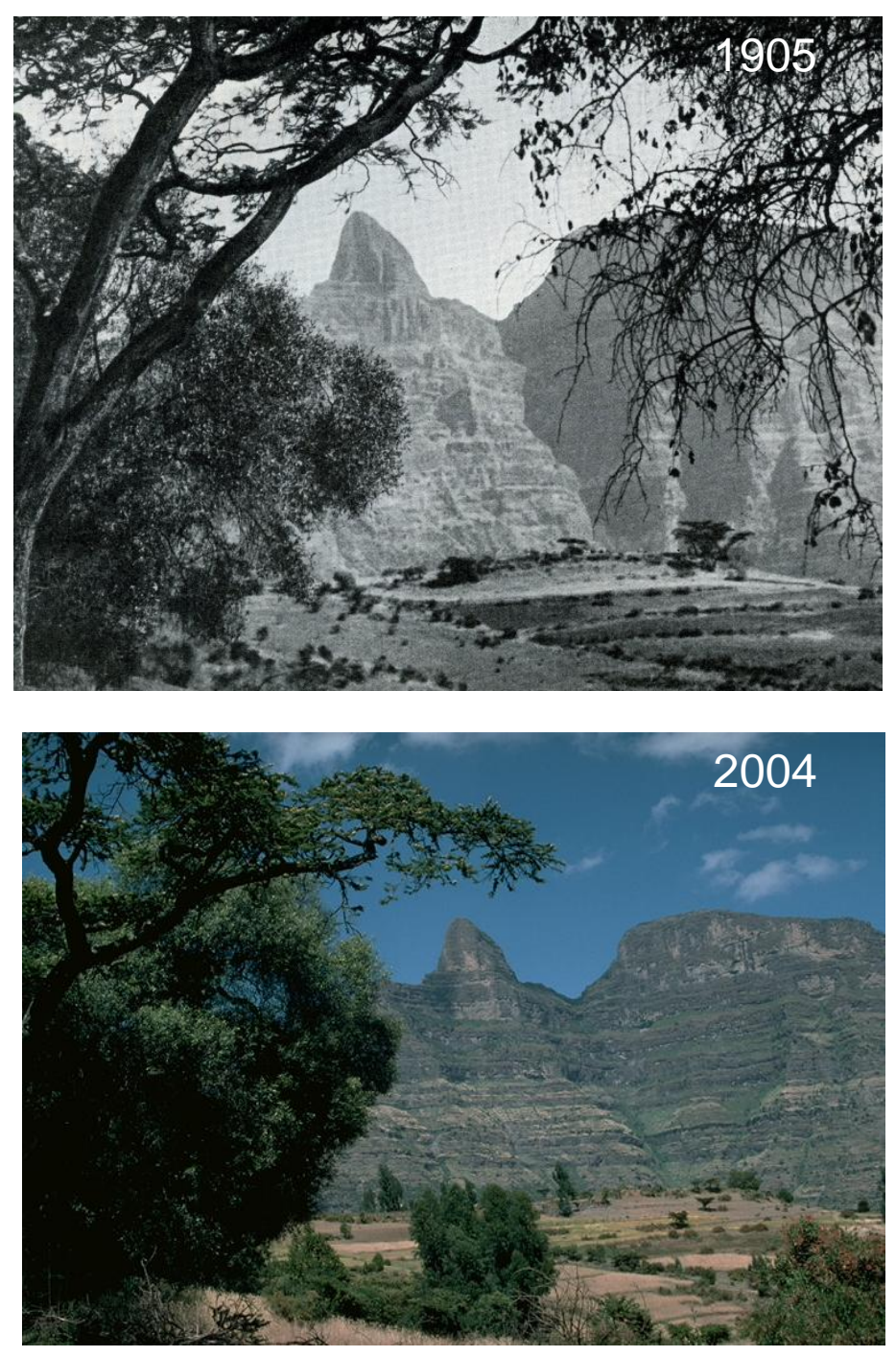
Fig. 3.
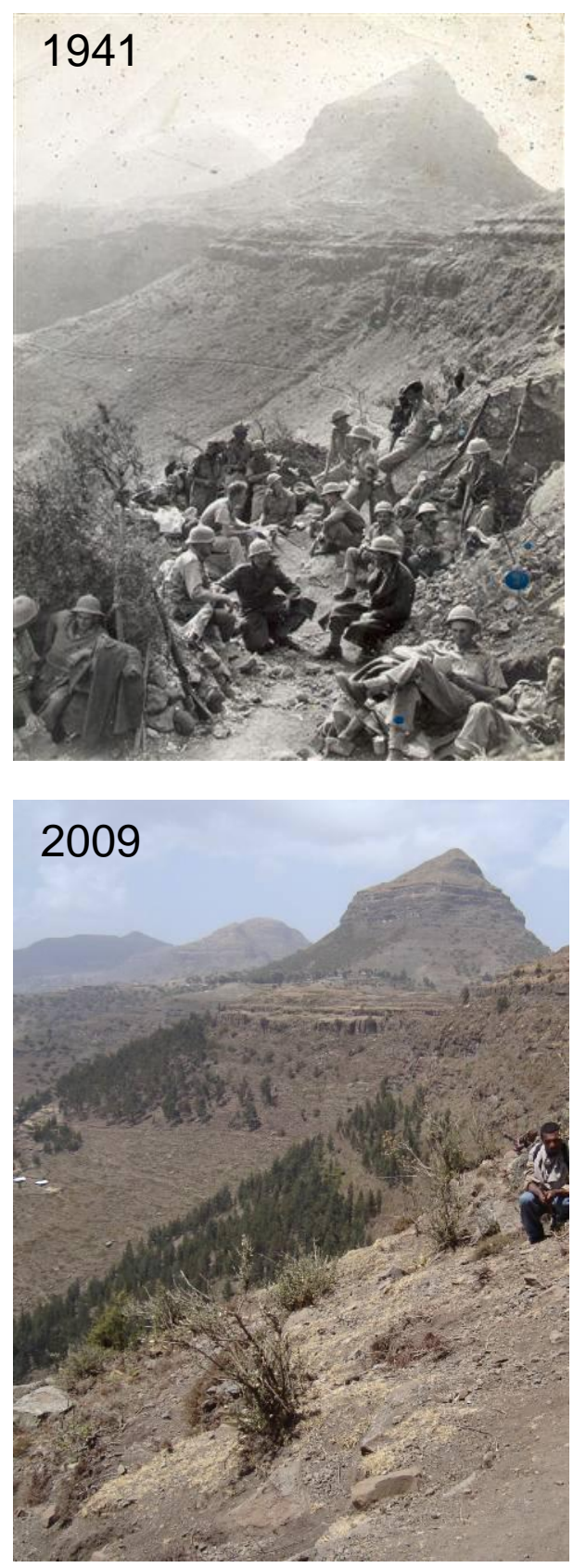
Fig. 4
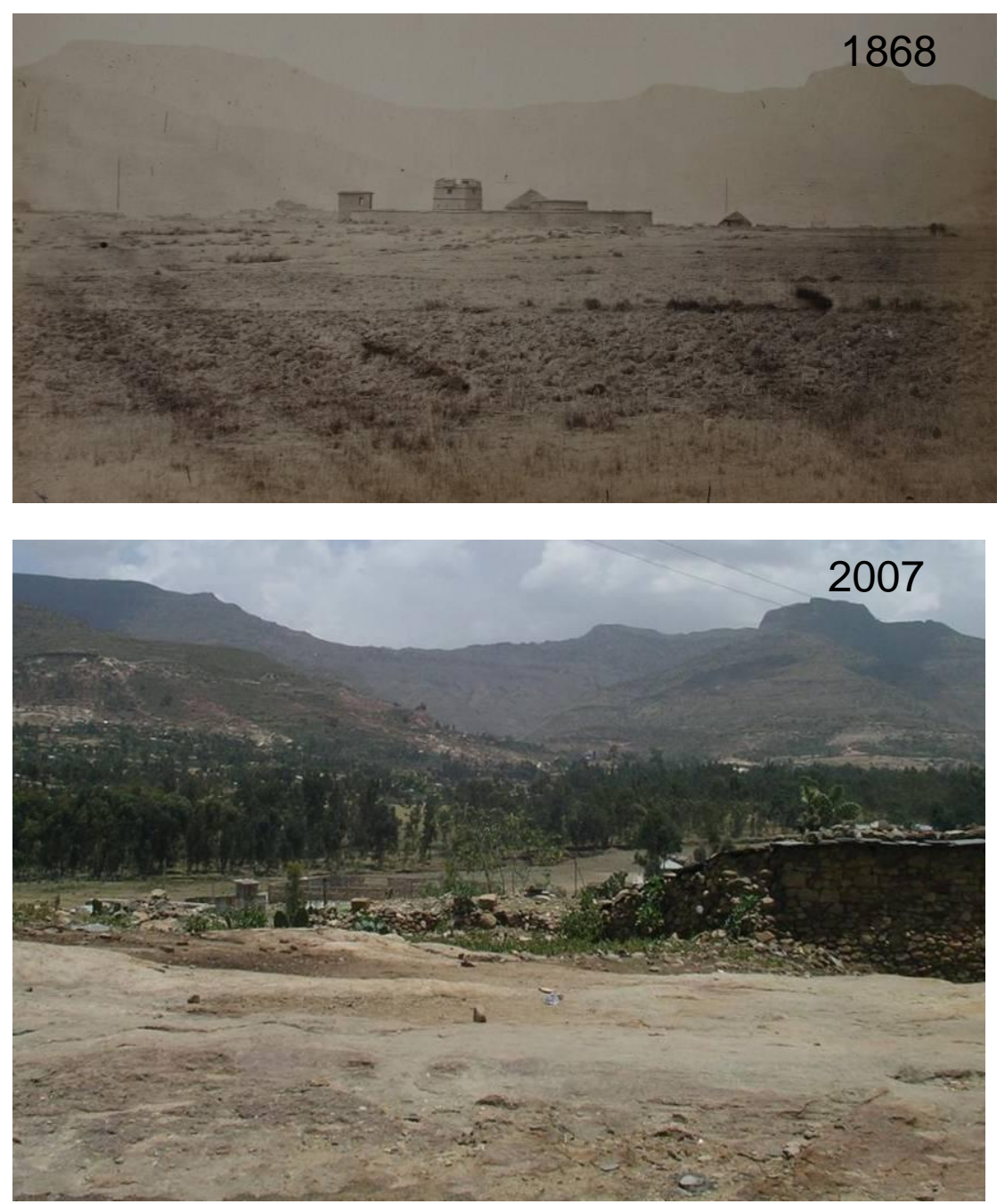
Fig. 5
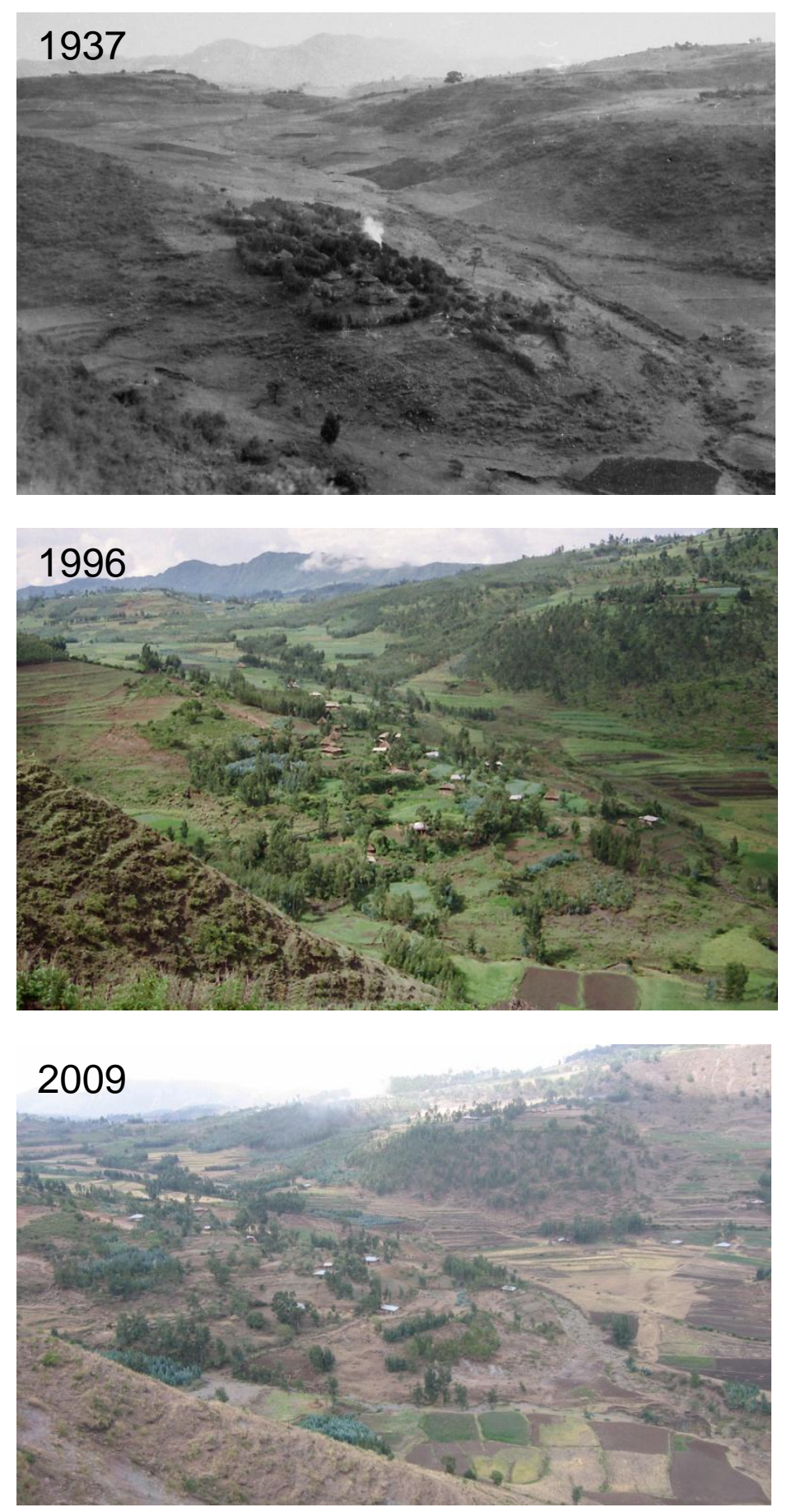
Fig. 6.
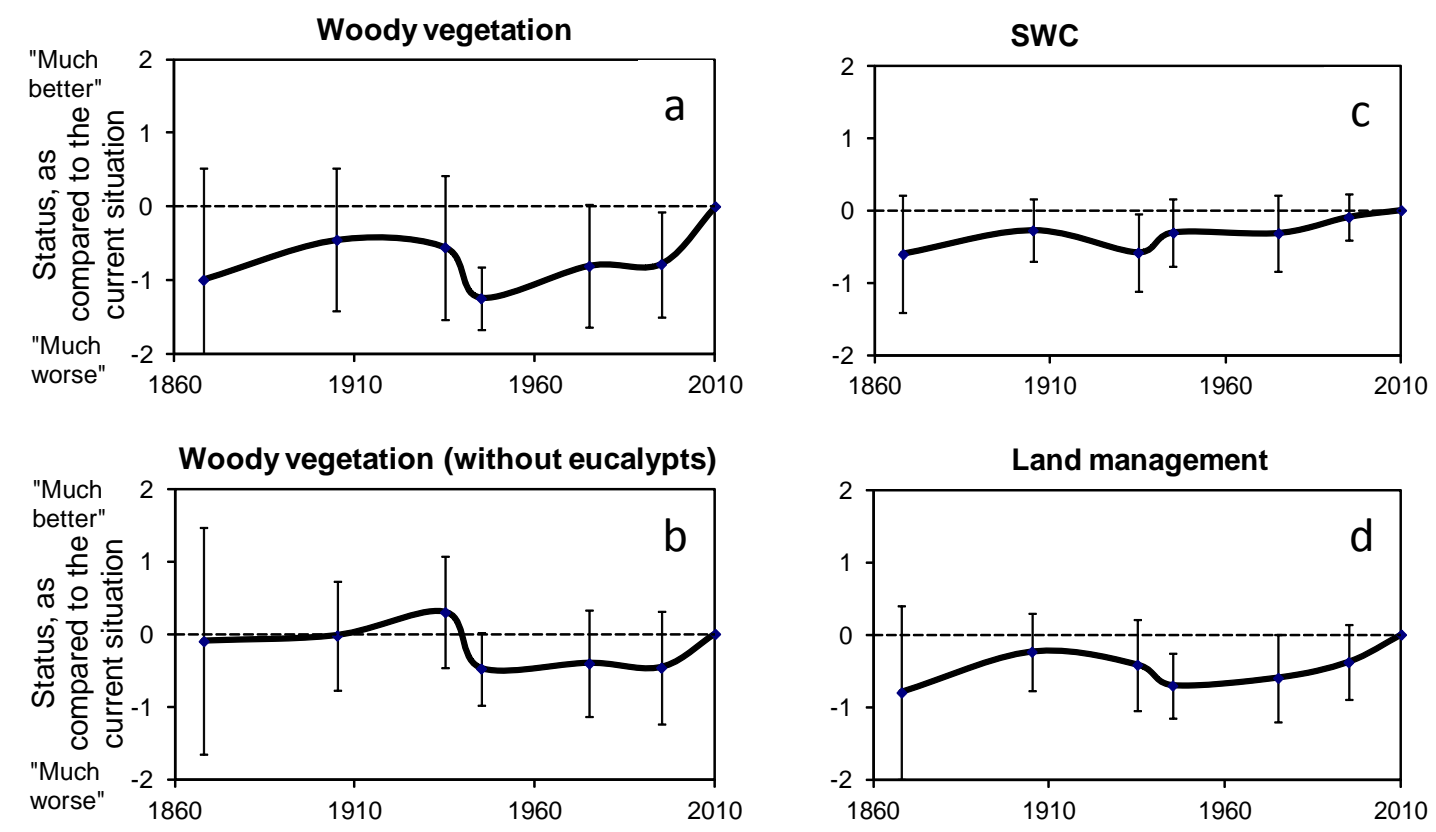
Fig. 7.
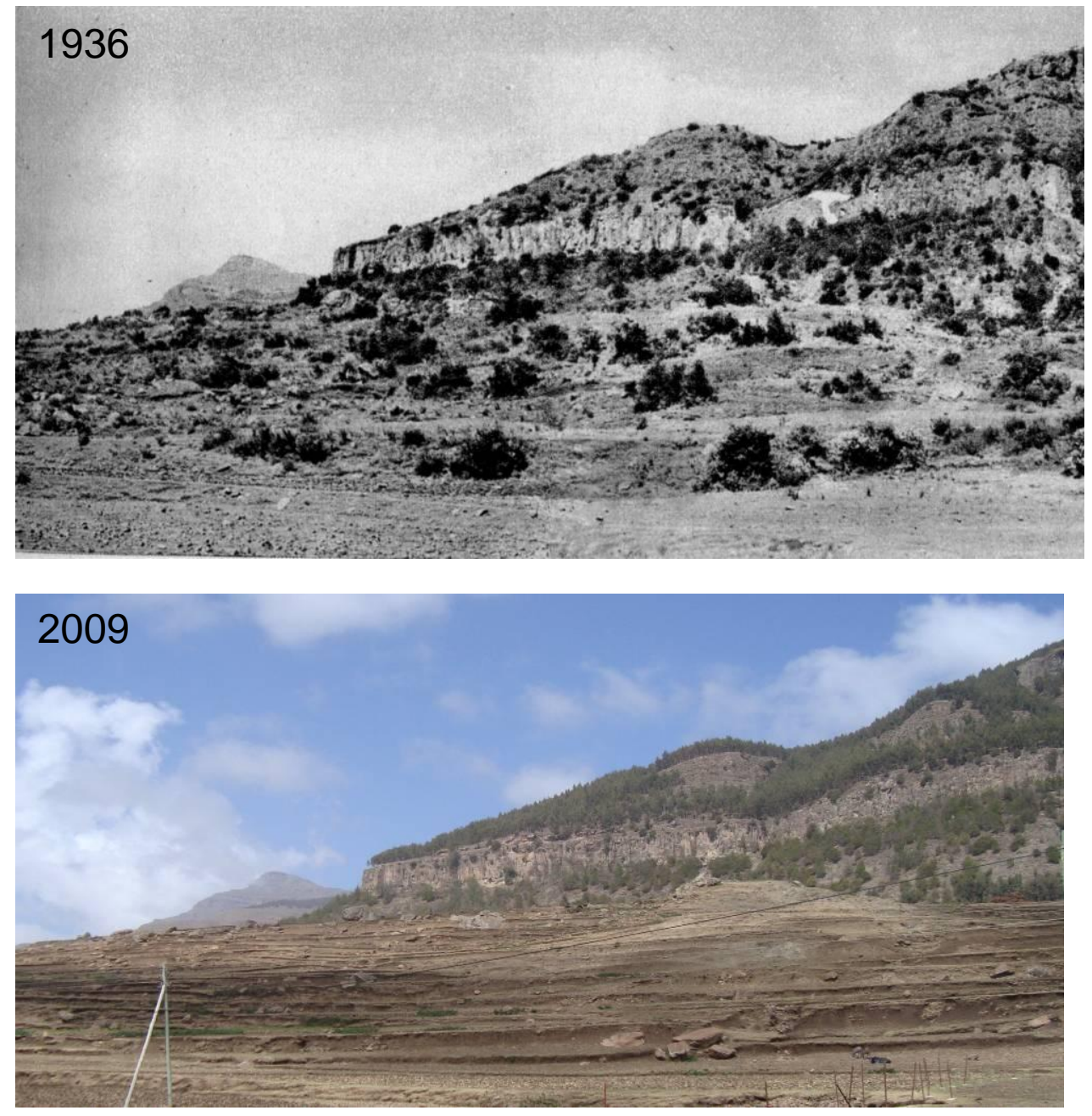
Fig. 8

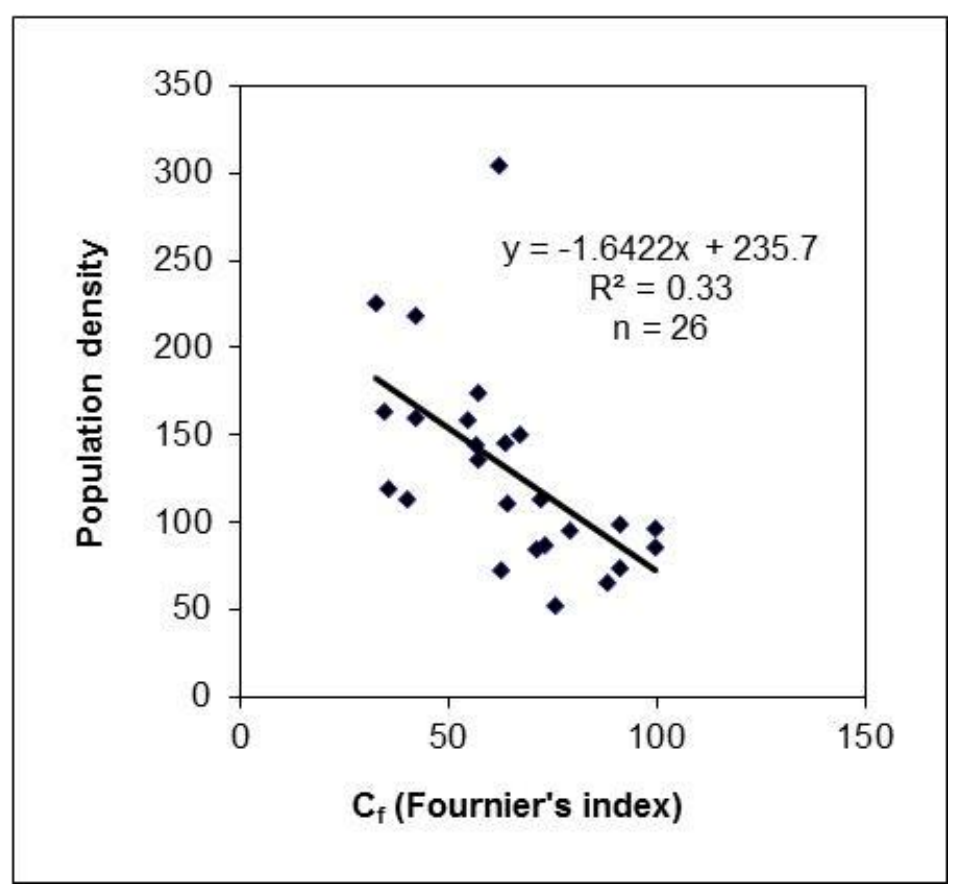


Fig. 9.
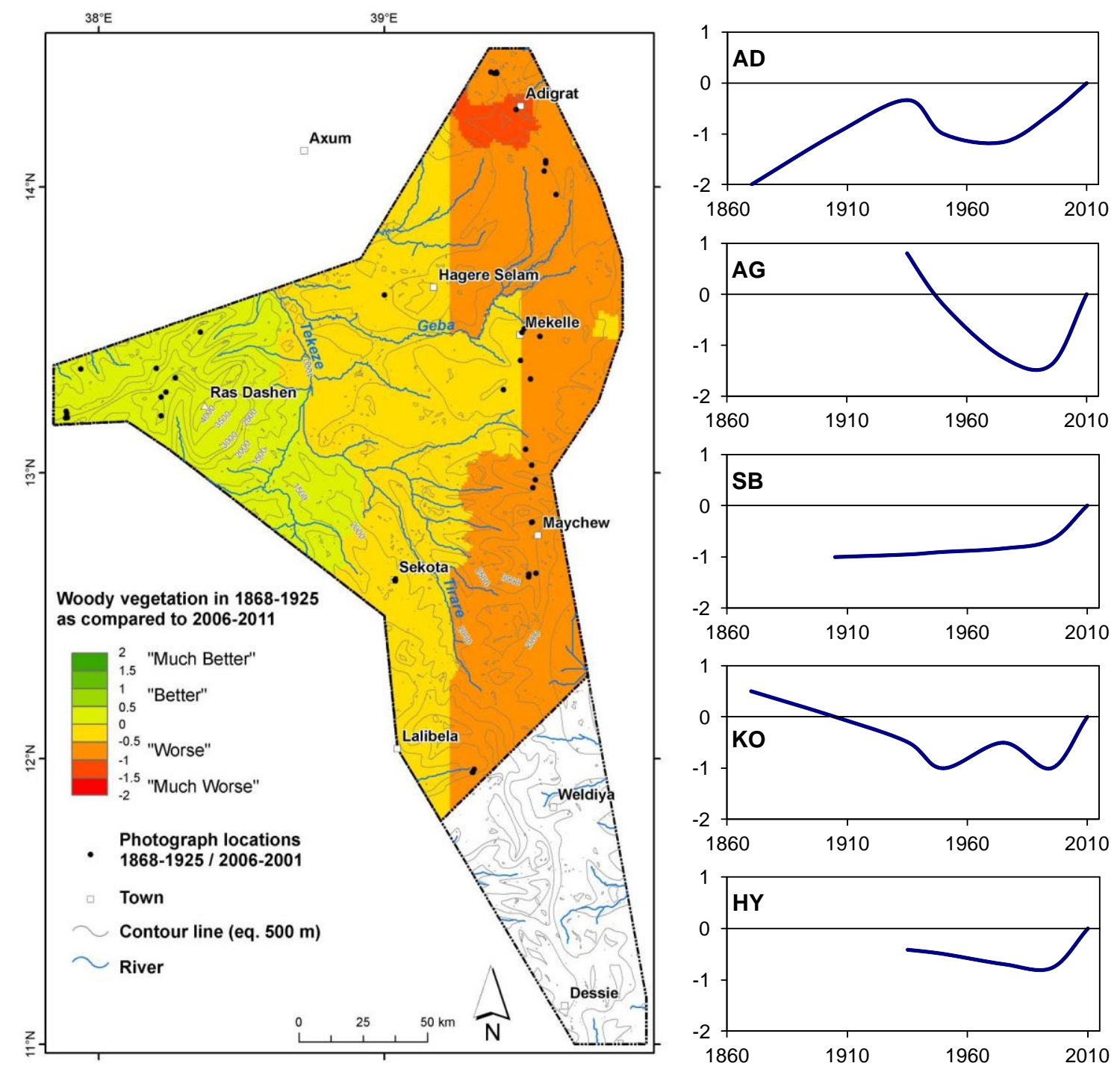
Fig. 10
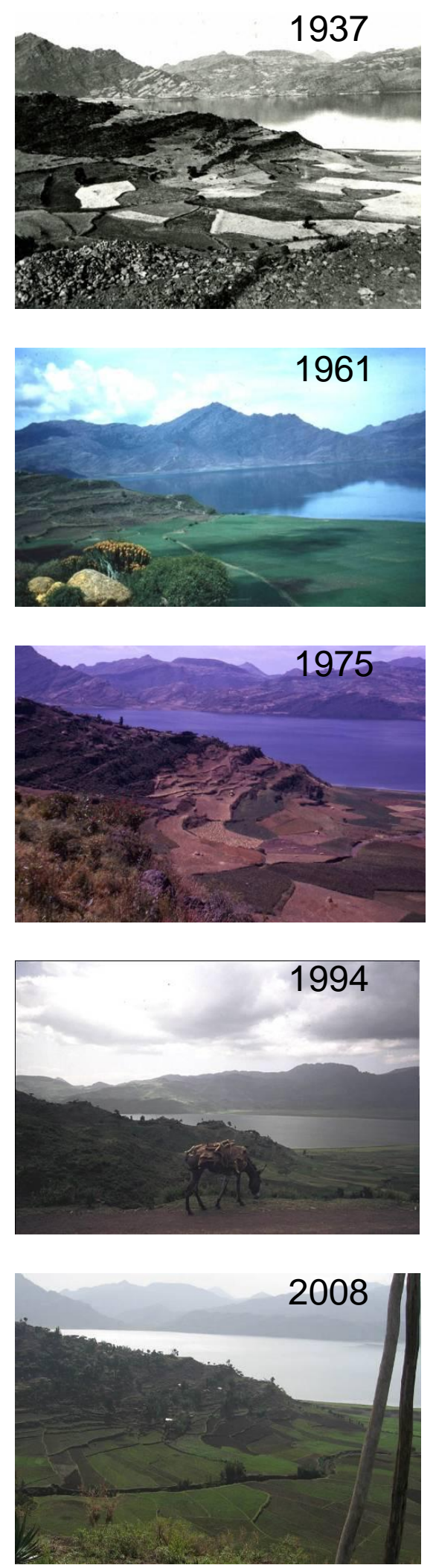
Fig. 11

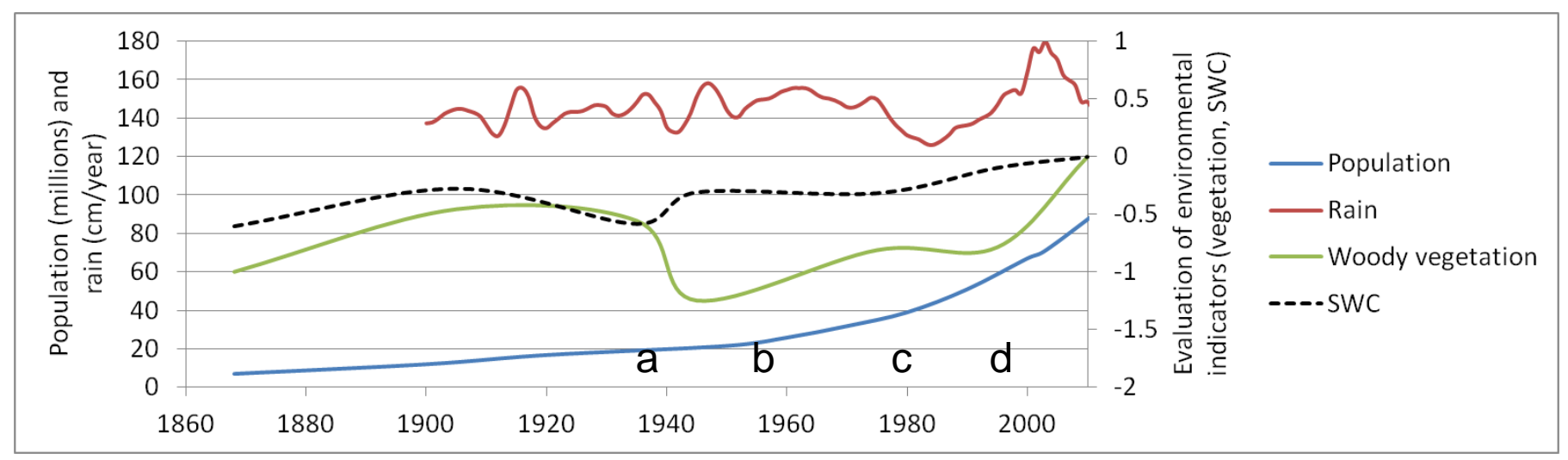


Fig. 12.
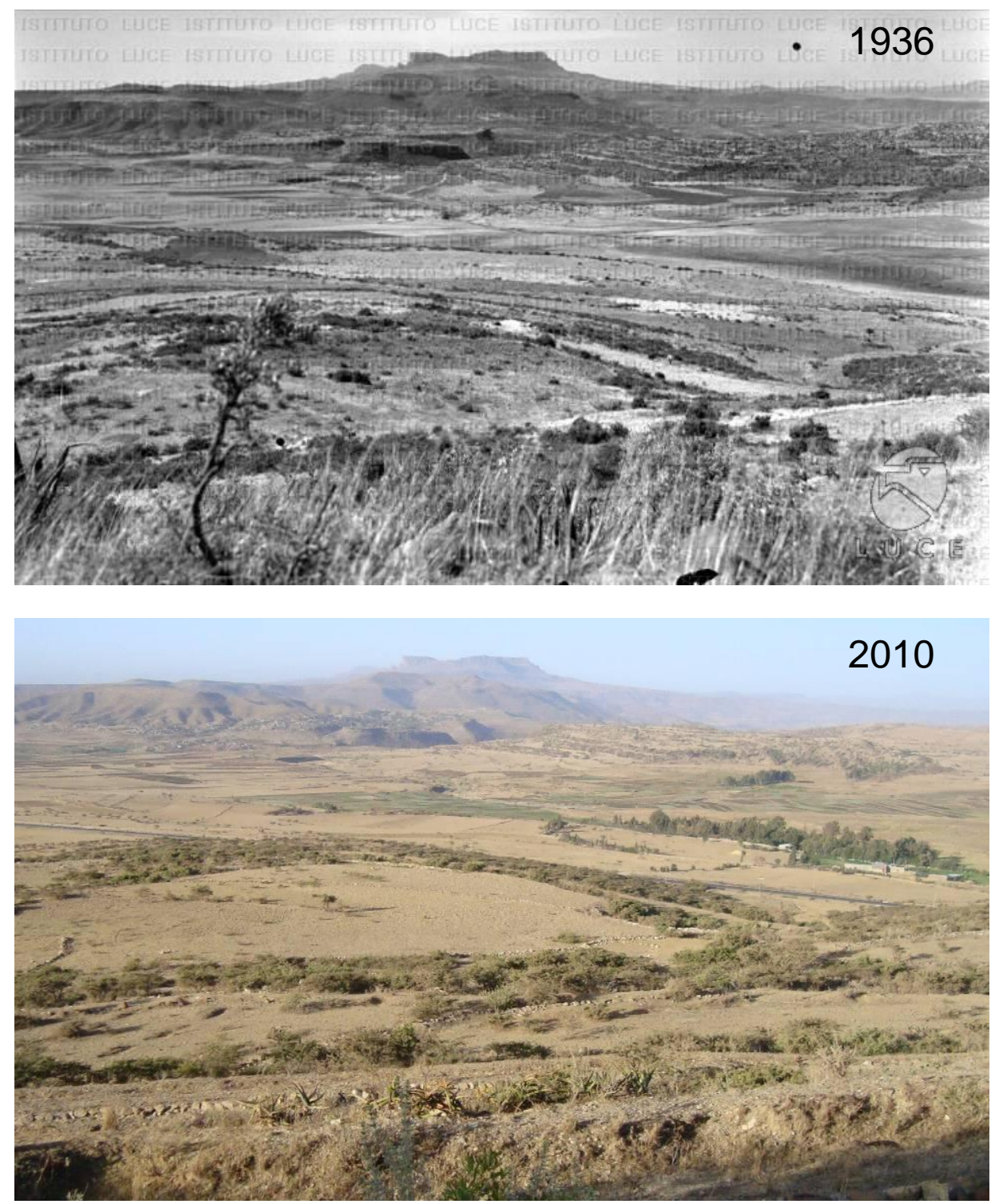
Fig. 13.
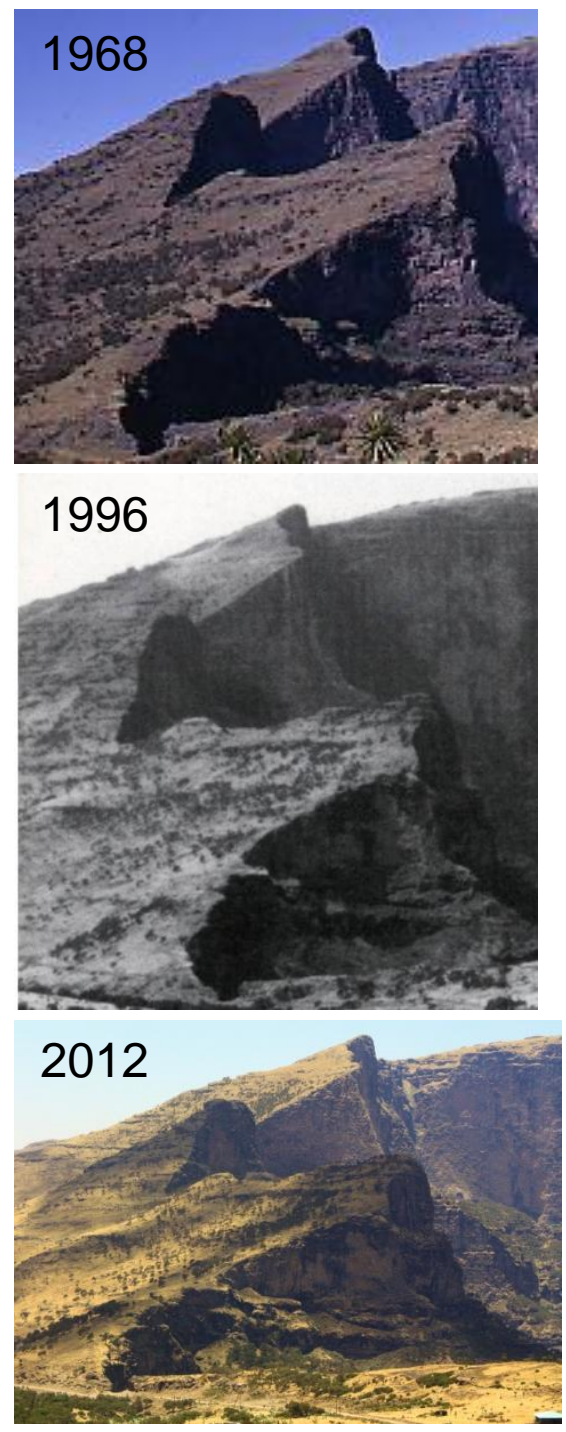


\section{Tables}

Table 1. Overview of landscape photographs used in this study

\begin{tabular}{|c|c|c|c|c|c|c|c|c|c|c|c|c|c|}
\hline & \multirow[t]{2}{*}{ Polygon name* } & \multicolumn{2}{|c|}{ Polygon center } & \multicolumn{9}{|c|}{ Number of historical landscape photographs per epoch } & \multirow[t]{2}{*}{ Total per polygon } \\
\hline & & Lat. $\mathrm{N}$ & Long. E & 1868 & $1895-1909$ & $1910-1929$ & $1930 \mathrm{~s}$ & $1940 \mathrm{~s}$ & $1960 \mathrm{~s}$ & 1970s & 1980s & $1990 \mathrm{~s}$ & \\
\hline $\mathrm{AB}$ & Abi Adi & $13^{\circ} 37.5^{\prime}$ & $39^{\circ} 0^{\prime}$ & & & 1 & 7 & & & 3 & & 1 & 12 \\
\hline $\mathrm{AD}$ & Adigrat & $14^{\circ} 22.5^{\prime}$ & $39^{\circ} 22.5^{\prime}$ & 1 & 1 & & 3 & 1 & & 3 & & & 9 \\
\hline $\mathrm{AG}$ & Agula & $13^{\circ} 37.5^{\prime}$ & $39^{\circ} 37.5^{\prime}$ & & & & 5 & & & 17 & & 9 & 31 \\
\hline $\mathrm{AL}$ & Alamata & $12^{\circ} 27.5^{\prime}$ & $39^{\circ} 30^{\prime}$ & & & & 1 & & & 4 & & 1 & 6 \\
\hline $\mathrm{AM}$ & Adi Gudom & $13^{\circ} 7.5^{\prime}$ & $39^{\circ} 30^{\prime}$ & 1 & 1 & & 7 & & & & & & 9 \\
\hline DB & Debark & $13^{\circ} 22.5^{\prime}$ & $38^{\circ} 7.5^{\prime}$ & & 6 & & & & 4 & 2 & 2 & 5 & 19 \\
\hline DT & Dogua Tembien & $13^{\circ} 37.5^{\prime}$ & $39^{\circ} 10^{\prime}$ & & & & & & & 6 & & 2 & 8 \\
\hline HA & Hawzen & $13^{\circ} 52.5^{\prime}$ & $39^{\circ} 22.5^{\prime}$ & & & & 2 & & & 22 & & & 24 \\
\hline HY & Hayk & $11^{\circ} 20^{\prime}$ & $39^{\circ} 40^{\prime}$ & & & & 12 & & & & & 11 & 23 \\
\hline KM & Kombolcha & $11^{\circ} 5^{\prime}$ & $39^{\circ} 45^{\prime}$ & & & & 6 & & & & & 6 & 12 \\
\hline $\mathrm{KO}$ & Korem & $12^{\circ} 37.5^{\prime}$ & $39^{\circ} 30^{\prime}$ & 3 & & & 17 & & 2 & 4 & 2 & 2 & 30 \\
\hline $\mathrm{KU}$ & Kulmesq & $11^{\circ} 57.5^{\prime}$ & $39^{\circ} 2.5^{\prime}$ & 2 & & & & & & & & & 2 \\
\hline KW & Kwiha & $13^{\circ} 22.5^{\prime}$ & $39^{\circ} 33.75^{\prime}$ & & & & 6 & & & 6 & & & 12 \\
\hline LA & Lahama & $13^{\circ} 22.5^{\prime}$ & $39^{\circ} 41.25^{\prime}$ & & & & & & & 6 & & & 6 \\
\hline LU & Lugda & $13^{\circ} 37.5^{\prime}$ & $39^{\circ} 52.5^{\prime}$ & & & & & & & 6 & & & 6 \\
\hline MA & Maychew & $12^{\circ} 52.5^{\prime}$ & $39^{\circ} 30^{\prime}$ & 4 & 1 & & 19 & 14 & 1 & 19 & & & 58 \\
\hline MK & Mekelle town & $13^{\circ} 28.5^{\prime}$ & $39^{\circ} 29.6^{\prime}$ & & 1 & & 9 & 1 & & 6 & & & 17 \\
\hline $\mathrm{NE}$ & Nebelet & $14^{\circ} 7.5^{\prime}$ & $39^{\circ} 22.5^{\prime}$ & & & & & & & 1 & & & 1 \\
\hline $\mathrm{NM}$ & North Mekelle & $13^{\circ} 37.5^{\prime}$ & $39^{\circ} 22.5^{\prime}$ & & & & & & & 8 & & 1 & 9 \\
\hline SB & Simien Bwahit & $13^{\circ} 12^{\prime}$ & $38^{\circ} 10^{\prime}$ & & 1 & & & & 1 & 2 & & 3 & 7 \\
\hline SD & Simien Dashen & $13^{\circ} 15^{\prime}$ & $38^{\circ} 24^{\prime}$ & & 3 & & & & & & & & 3 \\
\hline SE & Senkata & $14^{\circ} 7.5^{\prime}$ & $39^{\circ} 37.5^{\prime}$ & 2 & 1 & & 1 & & & 5 & & & 9 \\
\hline SK & Sokota & $12^{\circ} 37.5^{\prime}$ & $39^{\circ} 2.5^{\prime}$ & & & 2 & & & & & & & 2 \\
\hline SM & South Mekelle & $13^{\circ} 22.5^{\prime}$ & $39^{\circ} 26.25^{\prime}$ & 2 & 1 & & 1 & & & 3 & & & 7 \\
\hline $\mathrm{TE}$ & Tellemt & $13^{\circ} 22.5^{\prime}$ & $38^{\circ} 22.5^{\prime}$ & & 3 & & & & & & & & 3 \\
\hline WU & Wukro & $13^{\circ} 52.5^{\prime}$ & $39^{\circ} 37.5^{\prime}$ & & & & 5 & & & 21 & & 2 & 28 \\
\hline \multicolumn{4}{|c|}{ Various isolated locations within the study area } & & 2 & & 2 & 3 & & 1 & & & 8 \\
\hline & Total & & & 15 & 21 & 3 & 103 & 19 & 8 & 145 & 4 & 43 & 361 \\
\hline
\end{tabular}

*Corresponds to the name of the topographic map, except for those areas where additional polygons were introduced to better represent the variability in ecology (elevation) and urbanization. 
Table 2. Possible explanatory variables for environmental changes in the northern Ethiopian Highlands

\begin{tabular}{|c|c|c|c|c|c|c|c|c|c|c|c|c|}
\hline Polyg & $\mathrm{P}_{\mathrm{y}}{ }^{\mathrm{a}}$ & $\mathrm{C}_{\mathrm{f}}^{\mathrm{b}}$ & $\mathrm{T}_{\mathrm{y}}^{\mathrm{c}}$ & $A^{d}$ & $\mathrm{~d}^{\mathrm{e}}$ & Dist $^{f}$ & $\mathrm{~N}^{\mathrm{g}}$ & $\mathrm{E}^{\mathrm{h}}$ & $F_{o}^{j}$ & $\mathrm{~F}_{\mathrm{c}}^{\mathrm{k}}$ & $\mathrm{z}^{1}$ & SG \\
\hline Abi Adi & 731.16 & 78.98 & 20.58 & 1.8 & 96 & 54 & 13.63 & 39.00 & 7.1 & 0.0 & 871.4 & 9.0 \\
\hline Adigrat & 695.43 & 2.24 & 748 & 2.1 & 225 & 88 & 14.38 & 39.44 & 100.0 & .0 & 2429.5 & 2.4 \\
\hline refic & 1.72 & 9.98 & 0.18 & 0 & 113 & 22 & 13.63 & 3 & 00.0 & 0 & 4 & 8.0 \\
\hline $\mathrm{N}$ of Alamata & 11 & 92 & 4 & 8 & 160 & 116 & 46 & 0 & 3 & .7 & 5 & 7.5 \\
\hline & & 3 & .09 & 1.7 & 87 & 42 & & 0 & 00.0 & 0 & & 10. \\
\hline ebark & 1048.7 & 8.05 & 2.06 & 4.5 & 66 & 11 & 1 & 38 & 80.4 & 0.0 & 1 & 23. \\
\hline$n$ & 53.41 & 71.78 & .64 & 1.8 & 114 & 37 & .63 & .17 & 49.2 & .0 & 6 & 1.8 \\
\hline av & 677.17 & 56.79 & 0.57 & 1.7 & 137 & 44 & 13.88 & 39.38 & 73.7 & 0.0 & 8 & 7.5 \\
\hline Hayk & 1101.9 & 61.9 & 17.9 & 3.2 & 304 & 23 & 1.33 & 39.67 & 79.3 & 0.0 & 6.7 & 12.2 \\
\hline Komb & 1003.7 & 56.94 & 17.81 & 2.9 & 174 & 14 & 11.08 & 39.75 & 80.6 & 0.0 & 1976.6 & 12. \\
\hline orent & 105.92 & 66.92 & 4.94 & 2.7 & 150 & 97 & 12.63 & 39.50 & 100.0 & 51.4 & 7 & 16 \\
\hline 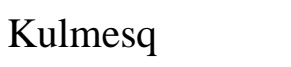 & 1049.1 & 54.22 & 19.32 & 2.8 & 159 & 112 & 11.96 & 39.04 & 100.0 & 0 & .8 & 15 \\
\hline $1 \mathrm{~d}$ & 619.49 & 56.53 & 18.32 & 1.8 & 144 & 16 & 13.38 & 39.56 & 100.0 & .0 & .4 & 5.2 \\
\hline Lahama & 562.15 & 1 & 7 & 1.6 & 99 & 36 & 3 & 9 & 97.9 & 0.0 & 1 & 11 \\
\hline da & 667.43 & 62.72 & 18.36 & 1.9 & 73 & 48 & 13.67 & 39.88 & 38.8 & 0.0 & 0.7 & 14.8 \\
\hline IVIa & 141.15 & 63.7 & 5.39 & 2.5 & 145 & 69 & 12. & 39.50 & 100.0 & 4.5 & 4 & 17 \\
\hline Mekel & 615.62 & 65.44 & 20 & 1.6 & 871 & 0 & 13.48 & 39.49 & 100.0 & 0.0 & 2147.3 & 3.9 \\
\hline NEUEIEl & 091.10 & 41.97 & 16.2 & 2.2 & 218 & 71 & 14.13 & 39.44 & 100.0 & 0.0 & 2409.7 & 9.5 \\
\hline North Mekelle & 687.35 & 64.06 & 7.18 & 2.1 & 111 & 19 & 13.63 & 39.38 & 56.9 & 0.0 & 2066.8 & 8 \\
\hline Simien Bwahit & 1515 & 99.37 & 8.8 & 8.8 & 97 & 103 & 13.20 & 38.18 & 5.6 & 0.0 & 3597.8 & 17 \\
\hline
\end{tabular}




$\begin{array}{lrrrrrrrrrrrr}\text { Simien Dashen } & 1515 & 99.37 & 9.17 & 8.4 & 86 & 119 & 13.27 & 38.41 & 64.4 & 0.0 & 3600.3 & 21.5 \\ \text { Senkata } & 706.89 & 34.24 & 15.63 & 2.4 & 164 & 71 & 14.13 & 39.56 & 100.0 & 0.0 & 2550.5 & 6.5 \\ \text { Sokota } & 930.03 & 75.7 & 20.96 & 2.3 & 52 & 108 & 12.63 & 39.04 & 36.7 & 0.0 & 2053.4 & 12.1 \\ \text { South Mekelle } & 650.27 & 70.83 & 21.03 & 1.5 & 85 & 14 & 13.38 & 39.44 & 100.0 & 0.0 & 2160.7 & 7.1 \\ \text { Tellemt } & 993.49 & 91.13 & 14.03 & 3.5 & 73 & 120 & 13.38 & 38.38 & 81.6 & 0.0 & 2695.2 & 24.3 \\ \text { Wukro } & 705.49 & 35.24 & 16.53 & 2.1 & 120 & 43 & 13.88 & 39.63 & 100.0 & 0.0 & 2380.9 & 7.9\end{array}$

${ }^{\mathrm{a}} \mathrm{P}_{\mathrm{y}}=$ the mean annual precipitation at the center of the polygon, as interpolated using the NewLocClim software (FAO, 2013) interpolation with a Gaussian distance function along a horizontal gradient (extrapolation not allowed) from the data of a max. of 10 nearest stations at a maximum distance of $100 \mathrm{~km}$ (for Sokota: $150 \mathrm{~km}$ away). For areas in the Simien Mountains above $3500 \mathrm{~m}$ a.s.1. (SB and SD), extrapolation between much lower lying stations was deemed unreliable, and only the reported measured values (Hurni, 1982) were used. ${ }^{b}$ Fournier's (1962) degradation coefficient $\left(C_{f}, m m\right): C_{f}=p^{2} / P_{y}$, where $p=$ monthly precipitation (mm) during the wettest month and $\mathrm{P}_{\mathrm{y}}=$ annual precipitation $(\mathrm{mm})$; large values indicate a high potential for degradation. ${ }^{\mathrm{c}} \mathrm{T}_{\mathrm{y}}=$ the mean annual air temperature at the center of the polygon, as interpolated using the NewLocClim software (FAO, 2013) - inter- and extrapolation with a Gaussian distance function along a vertical gradient from data of max. 10 nearest stations, maximum $100 \mathrm{~km}$ away (for Sokota: 150 $\mathrm{km}) .{ }^{\mathrm{d}}$ Aridity index (Peel et al., 2007): $\mathrm{A}=0.05\left(\mathrm{P}_{\mathrm{y}}+28\right) / \mathrm{T}_{\mathrm{y}}$; lower values indicate high aridity. ${ }^{\mathrm{e}} \mathrm{d}=$ the mean population density of the polygon, as derived from gridded data pertaining to 2005 (CIESIN and CIAT, 2005). ${ }^{\mathrm{f}}$ Distance from major town (km), usually Mekelle but also Gondar (for Debark and Simien Bwahit) and Dessie (for Hayk, Kombolcha and Kulmesq). ${ }^{\mathrm{g}}$ Latitude, in ${ }^{\circ} \mathrm{N}$. ${ }^{\mathrm{h}}$ Longitude, in ${ }^{\circ} \mathrm{E} .{ }^{\mathrm{j}} \mathrm{F}_{\mathrm{o}}=$ original forest cover, corresponding to the areal forest cover of the polygon before the start of human intervention (in \%) (Bryant et al., 1997). ${ }^{\mathrm{k}} \mathrm{F}_{\mathrm{c}}=$ current forest cover, corresponding to the areal forest cover of the polygon in 1997 (in \%) (Bryant et al., 1997). ${ }^{1} \mathrm{z}=$ the mean elevation (in $\mathrm{m}$ a.s.l.) of each polygon, obtained from a Digital Terrain Model at a resolution of $90 \mathrm{~m}$ (SRTM, 2013). ${ }^{\mathrm{m}} \mathrm{SG}=$ the mean slope gradient (in degrees) of each polygon (SRTM, 2013). 
Table 3. Correlations between explanatory variables ${ }^{\mathrm{a}}$ for observed changes in the northern Ethiopian Highlands $(\mathrm{n}=26)$.

\begin{tabular}{|c|c|c|c|c|c|c|c|c|c|c|c|c|}
\hline & $\mathrm{P}_{\mathrm{y}}$ & $\mathrm{C}_{\mathrm{f}}$ & $\mathrm{T}_{\mathrm{y}}$ & $\mathrm{A}$ & $\mathrm{d}$ & Dist & $\mathrm{N}$ & $\mathrm{E}$ & $\mathrm{z}$ & SG & $F_{c}$ & $\mathrm{~F}_{\mathrm{o}}$ \\
\hline $\mathrm{P}_{\mathrm{y}}$ & 1 & $0.50 * *$ & $-0.72 * *$ & $0.93 * *$ & -0.04 & $0.57 * *$ & $-0.41 *$ & $-0.72 * *$ & $0.75 * *$ & $0.64 * *$ & -0.05 & $-0.40 *$ \\
\hline $\mathrm{C}_{\mathrm{f}}$ & $0.50 * *$ & 1 & -0.35 & $0.55^{* *}$ & $-0.57 * *$ & 0.25 & -0.15 & $-0.66^{* *}$ & 0.35 & $0.51 * *$ & -0.11 & $-0.51 * *$ \\
\hline $\mathrm{T}_{\mathrm{y}}$ & $-0.72 * *$ & -0.35 & 1 & $-0.86 * *$ & -0.06 & $-0.60 * *$ & -0.01 & $0.63 * *$ & $-0.86 * *$ & $-0.70 * *$ & -0.19 & 0.15 \\
\hline A & $0.93 * *$ & $0.55^{* *}$ & $-0.86^{* *}$ & 1 & -0.15 & $0.55 * *$ & -0.15 &,$- 74 * *$ & $0.87 * *$ & $0.61 * *$ & -0.19 & $-0.40^{*}$ \\
\hline$d$ & -0.04 & $-0.57 * *$ & -0.06 & -0.15 & 1 & -0.17 & -0.28 & $0.42 *$ & 0.10 & -0.22 & 0.13 & 0.38 \\
\hline Dist & $0.57 * *$ & 0.25 & $-0.60 * *$ & $0.55^{* *}$ & -0.17 & 1 & -0.04 & $-0.66 * *$ & $0.65 * *$ & $0.77 * *$ & 0.32 & -0.15 \\
\hline $\mathrm{N}$ & $-0.41 *$ & -0.15 & -0.01 & -0.15 & -0.28 & -0.04 & 1 & -0.06 & 0.02 & -0.28 & -0.24 & -0.02 \\
\hline $\mathrm{E}$ & $-0.72 * *$ & $-0.66 * *$ & $0.63 * *$ & $-0.74 * *$ & $0.42^{*}$ & $-0.66 * *$ & -0.06 & 1 & $-0.66 * *$ & $-0.64 * *$ & 0.14 & $0.45^{*}$ \\
\hline $\mathrm{z}$ & $0.75 * *$ & 0.35 & $-0.86^{* *}$ & $0.87 * *$ & 0.10 & $0.66^{* *}$ & 0.02 & $-0.66^{* *}$ & 1 & $0.59 * *$ & 0.12 & -0.08 \\
\hline SG & $0.64 * *$ & $0.51 * *$ & $-0.70 * *$ & $0.61 * *$ & -0.22 & $0.77 * *$ & -0.28 & $-0.64 * *$ & $0.59 * *$ & 1 & 0.26 & -0.17 \\
\hline $\mathrm{F}_{\mathrm{c}}$ & -0.05 & -0.11 & -0.19 & -0.013 & 0.13 & 0.32 & -0.24 & 0.14 & 0.12 & 0.26 & 1 & 0.21 \\
\hline $\mathrm{F}_{\mathrm{o}}$ & $-0.40 *$ & $-0.51 * *$ & -0.15 & $-0.40^{*}$ & 0.38 & -0.15 & -0.02 & $0.45 *$ & -0.08 & -0.17 & 0.21 & 1 \\
\hline
\end{tabular}

${ }^{\mathrm{a}}$ For the definitions and the methods of the computation of the variables, see Table 2.

* Correlation is significant at the 0.05 level (2-tailed), ** Correlation is significant at the 0.01 level (2-tailed). 
Table 4. Pearson correlation coefficients among explanatory factors ${ }^{\mathrm{a}}$ and observed changes; the value in italics is the number of observations used to determine the correlation coefficient.

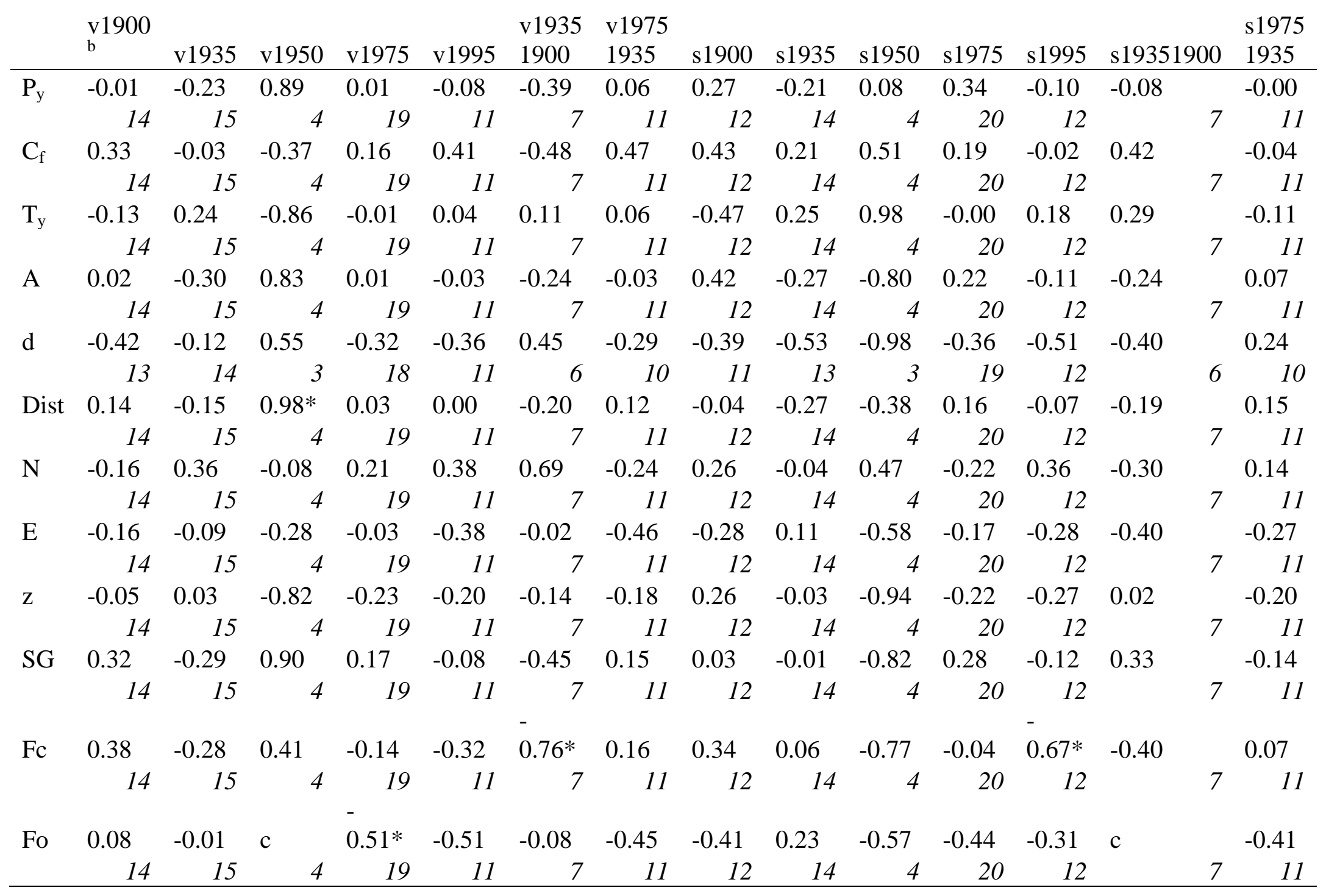


${ }^{a}$ For the definitions and the methods of computation of the variables, see Table $2 .{ }^{b}$ The indicators of environmental change are named with a letter ( $\mathrm{v}$ for woody vegetation, and s for SWC structure density) and the central year of the time period considered. For example, v1900 stands for the rating of woody vegetation cover for the period from 1868-1925, centered on 1900, in comparison to the situation from 2006-2011. 19751935 and 19351900 stand for the comparisons between the ratings for 1975 and 1935 , viz. 1935 and 1900. ${ }^{\mathrm{c}}$ The correlation coefficient cannot be computed because the independent variable is constant.

* Correlation is significant at the 0.05 level (2-tailed), ** Correlation is significant at the 0.01 level (2-tailed) 
Table 5. Multiple regression equations expressing the ratings for woody vegetation cover at different epochs as a function of the degradation coefficient $\left(\mathrm{C}_{\mathrm{f}}\right)$, population density $(\mathrm{d})$, latitude $(\mathrm{N})$, current forest cover $\left(\mathrm{F}_{\mathrm{c}}\right)$ and original forest cover $\left(\mathrm{F}_{\mathrm{o}}\right)$. For every factor, the coefficient and level of significance are given.

\begin{tabular}{|c|c|c|c|c|c|c|c|c|c|c|c|c|c|c|c|}
\hline \multirow{3}{*}{$\begin{array}{l}\text { Dependent } \\
\text { variable }\end{array}$} & \multicolumn{10}{|c|}{ Independent variables } & \multirow{3}{*}{ constant } & \multirow[t]{3}{*}{$\mathrm{R}^{2}$} & \multirow[t]{3}{*}{$\mathrm{P}$} & \multirow[t]{3}{*}{$\mathrm{n}$} & \multirow[t]{3}{*}{ eq. } \\
\hline & \multicolumn{2}{|c|}{$\mathrm{C}_{\mathrm{f}}$} & \multicolumn{2}{|c|}{$\mathrm{d}$} & \multicolumn{2}{|c|}{$\mathrm{N}$} & \multicolumn{2}{|c|}{$\mathrm{F}_{\mathrm{o}}$} & \multicolumn{2}{|c|}{$\overline{F_{c}}$} & & & & & \\
\hline & coeff. & $\mathrm{P}$ & coeff. & $\mathrm{P}$ & coeff. & $\mathrm{P}$ & coeff. & $\mathrm{P}$ & coeff. & $\mathrm{P}$ & & & & & \\
\hline v1900 & & & -0.014 & 0.019 & 0.361 & 0.342 & 0.011 & 0.137 & 0.034 & 0.064 & -4.739 & 0.59 & 0.097 & 13 & (4) \\
\hline v1935 & & & & & 0.273 & 0.182 & & & & & -4.196 & 0.13 & 0.182 & 14 & (5) \\
\hline v1975 & & & & & 0.301 & 0.342 & -0.011 & 0.026 & & & -3.884 & 0.31 & 0.054 & 19 & (6) \\
\hline v1995 & & & & & & & -0.009 & 0.114 & & & 0.053 & 0.26 & 0.114 & 11 & (7) \\
\hline v19351900 & & & 0.009 & 0.137 & & & & & -0.034 & 0.049 & -0.524 & 0.82 & 0.076 & 6 & (8) \\
\hline v19751935 & 0.022 & 0.149 & & & & & & & & & -1.614 & 0.22 & 0.149 & 11 & (9) \\
\hline
\end{tabular}

Table 6. Multiple regression equations expressing the ratings for SWC at different epochs as a function of the degradation coefficient $\left(\mathrm{C}_{\mathrm{f}}\right)$, population density $(\mathrm{d})$, longitude $(\mathrm{E})$, current forest cover $\left(\mathrm{F}_{\mathrm{c}}\right)$ and original forest cover $\left(\mathrm{F}_{\mathrm{o}}\right)$. For every factor, the coefficient and level of significance are given.

\begin{tabular}{|c|c|c|c|c|c|c|c|c|c|c|c|c|c|c|c|}
\hline \multirow{3}{*}{$\begin{array}{l}\text { Dependent } \\
\text { variable }\end{array}$} & \multicolumn{10}{|c|}{ Independent variables } & \multirow{3}{*}{ constant } & \multirow[t]{3}{*}{$\mathrm{R}^{2}$} & \multirow[t]{3}{*}{$\mathrm{P}$} & \multirow[t]{3}{*}{$\mathrm{n}$} & \multirow[t]{3}{*}{ eq. } \\
\hline & \multicolumn{2}{|c|}{$\overline{C_{f}}$} & \multicolumn{2}{|c|}{$\mathrm{d}$} & \multicolumn{2}{|c|}{$\mathrm{E}$} & \multicolumn{2}{|c|}{$\mathrm{F}_{\mathrm{o}}$} & \multicolumn{2}{|c|}{$\overline{F_{c}}$} & & & & & \\
\hline & coeff. & $\mathrm{P}$ & coeff. & $\mathrm{P}$ & coeff. & $\mathrm{P}$ & coeff. & $\mathrm{P}$ & coeff. & $\mathrm{P}$ & & & & & \\
\hline s1900 & & & -0.004 & 0.281 & & & -0.009 & 0.141 & 0.019 & 0.075 & 0.535 & 0.56 & 0.111 & 11 & $(10)$ \\
\hline s1935 & & & -0.004 & 0.03 & 0.786 & 0.185 & & & & & -30.995 & 0.4 & 0.079 & 13 & (11) \\
\hline s1950 & & & -0.005 & 0.116 & & & & & & & 0.246 & 0.97 & 0.116 & 3 & (12) \\
\hline s1975 & & & & & & & -0.005 & 0.051 & & & 0.14 & 0.2 & 0.051 & 20 & (13) \\
\hline s1995 & -0.007 & 0.059 & & & -0.25 & 0.062 & & & -0.006 & 0.017 & 10.235 & 0.67 & 0.026 & 12 & (14) \\
\hline s19351900 & 0.071 & 0.014 & 0.017 & 0.027 & & & $*$ & & -0.037 & 0.012 & -6.065 & 0.98 & 0.026 & 6 & (15) \\
\hline s19751935 & & & 0.006 & 0.092 & 2.928 & 0.145 & -0.025 & 0.065 & & & -114.16 & 0.55 & 0.159 & 10 & (16) \\
\hline
\end{tabular}


